\title{
Relationship lending and the use of trade credit: the role of relational capital and private information
}

\author{
Pierluigi Murro (D) Valentina Peruzzi
}

Accepted: 24 June 2021 / Published online: 12 August 2021

(C) The Author(s) 2021

\begin{abstract}
Using a unique sample of Italian manufacturing firms, we investigate the impact of relationship lending on firms' use of trade credit. We find that firms maintaining close and long-lasting relationships with their main banks are associated with higher amounts of trade credit extended by suppliers. This result is robust to alternative measures of trade credit and relationship lending, and to different estimation techniques. We also analyze the mechanisms driving the association between relationship lending and the use of trade credit. Regression results suggest that the positive link between accounts payable and relationship lending is especially significant for firms that use to provide soft information to their lenders and for companies with greater relational abilities.

Plain English Summary The existence of close and long lasting lending relationships positively affects the amount of trade credit manufacturing firms receive from their suppliers. By relying on the Survey on Italian Manufacturing Firms, we show that the positive link between relationship lending and the use of
\end{abstract}

\section{P. Murro ( $\triangle)$}

Department of Business and Management, LUISS

University, Viale Romania 32 - 00197 Rome, Italy

e-mail: pmurro@luiss.it

\section{Peruzzi}

Department of Economics and Law, Sapienza University of Rome, Via Del Castro Laurenziano 9 - 00161 Rome, Italy

e-mail: valentina.peruzzi@uniroma1.it trade credit is driven by two channels: private information and relational capital. In a policy perspective, our findings reveal a need for banking regulation and supervision to encompass banking business models in evaluating banks. The current approach might not be suitable for local banks investing in soft information acquisition and could weaken SMEs' chances to receive both bank financing and trade credit from suppliers. Moreover, from a managerial point of view, our results uncover the relevance of firms' ability to create strong relationships with banks, suppliers, and other companies that may help alleviating financial constraints.

Keywords Trade credit · Relationship lending · Soft information $\cdot$ Relational capital

JEL Classifications D22 · G21 · G32

\section{Introduction}

Behind bank lending, trade credit is the most important source of external financing for small and medium-sized enterprises. In the USA, trade credit provides almost as much as debt financing to SMEs as bank loans (Berger \& Udell, 1995; Carbó-Valverde et al., 2016); in Europe, almost three out of four companies experience late payments and trade credit prevails over short-term bank financing (European Commission, 2015). Because of its widespread use, a large 
number of studies have investigated both the demand and supply side of trade credit and its relationship with bank financing. Two main opposite theories explain the link between trade and bank credit. The hypothesis of substitutability between bank and trade credit suggests that suppliers would extend more credit to customers when the latter face greater difficulties in borrowing from banks, so that, for the receiving firm, trade and bank credit would be imperfect substitutes (Garcia-Appendini \& Montoriol-Garriga, 2013; Casey \& O'Toole, 2014). By contrast, for the hypothesis of complementarity, as sellers have private information on buyers, the use of trade credit by the latter may translate into a signal of the firms' quality to financial intermediaries, thus mitigating credit rationing. From this perspective, trade credit and bank credit do not substitute each other, but might instead be complements (Biais \& Gollier, 1997; Deloof \& La Rocca, 2015).

In this paper, we contribute to this strand of the finance literature by focusing on the role played by the characteristics of the bank-firm relationship in determining the amount of trade credit received by firms. More specifically, we investigate whether the creation of closer and long-lasting lending relationships, i.e., the adoption of relationship lending technologies, significantly affects the use of trade credit by firms. As both suppliers and relationship bankers are more likely to extend credit when strong relationships exist and when the exchange of private information reduces asymmetric information problems, we expect that firms relying on relationship lending are also more likely to obtain trade credit in their business transactions. Two distinct channels should drive the positive link between trade credit and relationship lending: the type of information used by the relationship lender/supplier and the ability of the borrowing firm to create close relationships. First, firms that use to provide soft information to bank lenders may be more inclined to disclose the same type of data also to suppliers, thus increasing their chances to receive trade credit. Second, firms with strong relationships with bank lenders may use more trade credit because of their ability to create valuable relationships with business parties.

To address this issue, we draw information on firms' lending relationships and use of trade credit from the Survey on Italian Manufacturing Firms
(SIMF). ${ }^{1}$ The survey, conducted by the banking group UniCredit-Capitalia, covers a sample of almost 18,000 manufacturing firms for the years 1995-2006, and provide detailed information about firms' ownership structure, lending relationships, innovation, and internationalization activities. ${ }^{2}$ The same survey has recently been used as a testing ground for other objectives, such as studying the role of credit rationing on firm export decisions (Minetti \& Zhu, 2011), and investigating the impact of firm ownership structure on innovation activities and financial constraints (Minetti et al., 2015; Murro \& Peruzzi, 2019). By way of preview, estimation results indicate that firms maintaining strong lending relationships are associated with a higher use of trade credit. This finding is robust to alternative measures of relationship lending and trade credit, and to different estimation techniques aimed at accounting for endogeneity concerns. Then the analysis turns to investigate the channels affecting the positive association between relationship lending and the use of trade credit. Regression results suggest that the positive link between relationship lending and the amount of trade credit received is driven by the adoption of private information in both financing processes and by the firm's relational ability.

In providing these findings, we contribute to different strands of the current literature. First, we contribute to the literature on the link between trade credit and bank financing (Agostino \& Trivieri, 2014; Casey \& O'Toole, 2014; McGuinness et al., 2018) by showing that the nature of the bank-firm relationship significantly affects the use of trade credit. Second, we contribute to the literature on the benefits of relationship lending see, e.g., (Sette \& Gobbi, 2015; Bolton et al., 2016) by providing evidence that firms maintaining closer and long-lasting lending relationships obtain higher amounts of trade credit. Third, we highlight the role played by private informa-

\footnotetext{
${ }^{1}$ As highlighted by several studies, trade credit is particularly relevant for manufacturing firms ( $\mathrm{Ng}$ et al., 1999; Giannetti et al., 2011; Klapper et al., 2012). In fact, in traditional or manufacturing industries, where it is easier to repossess and resale the inputs, firms are better able to obtain trade credit financing when necessary (Mian \& Smith Jr, 1992; Psillaki \& Eleftheriou, 2015).

${ }^{2}$ Unfortunately, the 2004-2006 is the latest wave of the Survey on Italian Manufacturing Firms. For this reason, we cannot include the period after 2006 .
} 
tion and firms' relational abilities in shaping the link between relationship lending and trade credit (Kranton \& Minehart, 2001; Giannetti et al., 2011; Uchida et al., 2013).

The remainder of the paper is organized as follows. Section 2 presents the institutional background. Section 3 reviews the current literature on trade credit and relationship lending and lays out the hypotheses to be tested. Section 4 describes the dataset and the econometric approach. Section 5 discusses the main empirical results. In Section 6, we dissect the mechanisms underlying our main findings. Section 7 concludes.

\section{Institutional background}

Italy provides an ideal environment to study the link between relationship lending and the use of trade credit. First, as the stock market capitalization is still rather low, the Italian financial system is dominated by the banking sector. According to the World Bank data, in 2001 (roughly the middle year of our sample), the stock market capitalization as percentage of the gross domestic product was $45 \%$ in Italy, compared to $55 \%$ in Germany, $85 \%$ in France, and $131 \%$ in the USA (World Bank, 2002). Consistently with these figures, bank lending to non-financial corporations was much higher in Italy than in the other countries $(57 \%$ of GDP, compared to $43 \%$ in France and $36 \%$ in Germany). ${ }^{3}$ The primary role of banks and the relevance of relationship lending in the country also depend on the long-lasting tradition of local financial institutions and the predominance of small businesses, which use to engage in close and long-lasting lending relationships (Gambini and Zazzaro, 2013). ${ }^{4}$ Second, the use of trade credit is particularly common among Italian firms. The European Commission highlighted that almost three out of four (78\%) companies in Europe have experienced late payments between 2012 and 2015 (European Commission, 2015). However, while $80 \%$ of respondents in Italy reported experience of late payments, the equivalent figure was only $33 \%$ in the UK and 38\% in Germany. Trade credit appeared to

\footnotetext{
${ }^{3}$ See De Bonis et al. (2012) for more details.

${ }^{4}$ Angelini et al. (1998) show that the average length of banking relationships in Italy was 14 years in 1995, while Murro et al. (2020) report that more than $60 \%$ of Italian firms had a main bank located in the same province between 1995 and 2003.
}

be relatively more prevalent in Mediterranean countries also during the previous decade. Between 1993 and 2009, trade payables represented almost $30 \%$ of total sales in Italy, compared to $10 \%$ in Germany and $15 \%$ in France (ECB, 2011). The relevance of trade credit for Italian companies is confirmed by its clear prevalence over short-term bank financing. In 2000 , the ratio of trade payables to total assets was on average $30.3 \%$ against $16 \%$ of short-term bank debt (Russo and Leva, 2004). In this context, relationships with banks and suppliers result to be of the outmost importance for the financial life of many businesses, and analyzing the link between them may provide interesting insights about firms' financing behavior.

\section{Related literature and hypotheses framing}

\subsection{Trade credit and bank financing}

Trade credit is the finance provided by suppliers to facilitate commercial transactions (McGuinness et al., 2018). Firms act as financial intermediaries and extend credit to other firms by allowing them to buy goods and services and pay at a later scheduled date or exploit discounts for payments done before the due date. Because of its widespread use, several theories have tried to explain the advantages of trade credit. Most of the studies on this argument can be classified in two primary categories: theories based on real operations and theories based on financial aspects (Frank \& Maksimovic, 2005; Uchida et al., 2013). Real operations-based theories provide a set of motivations for the use of trade credit, including transaction cost minimization, price discrimination, and product quality guarantee. ${ }^{5}$ Theories based on financial motivations emphasize that trade creditors

\footnotetext{
${ }^{5}$ First, trade credit may reduce the transaction costs of paying bills by allowing buyers to cumulate obligations and pay them only monthly or quarterly. By mitigating the cost of paying bills every time goods are delivered, the use of trade credit enables a firm to separate the payment cycle from the delivery schedule (Petersen \& Rajan, 1997). Because the exchange of goods is separated from the immediate use of money, trade credit can also transform an uncertain stream of money payments, which is affected by demand and supply fluctuations, into a sequence that can be known with greater certainty (Ferris, 1981). Second, trade credit may be used to price discriminate (Brennan et al., 1988). When price discrimination is not legally allowed because of antitrust laws, high-priced trade credit may be a subsidy targeted at risky customers. While creditworthy customers
} 
may have certain advantages over financial institutions in offering credit to customers (Petersen and Rajan, 1997). First, suppliers may have an advantage over traditional lenders in assessing the creditworthiness of their clients. As suppliers and customers operate in closely related lines of business, suppliers use to visit buyers' premises more often than financial institutions do. This allows them to constantly monitor and evaluate the production activity of customer firms. The size and timing of the customer's orders can also provide information about the condition of the buyers' business. For instance, the buyer's inability to take advantage of early payment discounts may signal a deterioration in his creditworthiness to the supplier. In most cases, financial intermediaries could collect similar information but with longer time and at a higher cost. In some other cases, as suggested by Smith (1987) and Biais and Gollier (1997), suppliers can obtain information about customer quality that is unavailable to banks. Suppliers may also have a better ability to monitor trade debtors and enforce payments in comparison to specialized financial institutions. If there are few economical alternative sources other than the supplier, he can threaten to cut off future supplies if the borrower's actions can undermine the repayment capacity. This threat is particularly efficient when the buyer accounts for a small portion of the supplier's sales and no other suppliers are available in the market. ${ }^{6}$ Trade creditors are also less susceptible to the risk of strategically default because inputs are less liquid and thus less easily diverted than cash lent by banks (Burkart \& Ellingsen, 2004; Giannetti et al., 2011). Cunat (2007) suggests that stronger buyer-seller relationships can enhance debt

will find trade credit overpriced and repay it as soon as possible, risky customers will find it worthwhile to borrow because it is still cheaper than the other sources they have access to (Petersen \& Rajan, 1997). Suppliers may also have long-term interests in the survival of customer firms. Wilner (2000) shows that a dependent supplier may provide short-term financing to customers with temporary financial problems because his own profit is positively related to that of his customers. Third, trade credit may be used to signal product quality. In this case, the delay in payment can be considered as an implicit guarantee of the quality of goods. Such guarantees are particularly important for small and less well-established suppliers who want to signal product quality to larger creditworthy customers (Klapper et al., 2012).

${ }^{6} \mathrm{By}$ contrast, the threat to withdraw future finance by financial intermediaries may have little immediate effect on the borrower's actions. capacity by creating a repayment enforcement mechanism that is not available to banks and other creditors. Finally, trade creditors have some advantages in salvaging value from existing assets (Petersen and Rajan, 1997). When a borrower defaults, creditors are entitled to seize the firm's inputs and other assets to cover their losses. However, a repossessed input may be more valuable for the supplier than for the bank as the supplier is in the business of selling this good and the cost of repossessing and resale will be significantly lower. ${ }^{7}$

If suppliers are better than specialized financial institutions in evaluating and controlling the credit risk of their buyers, trade credit may be a way for firms with better access to credit markets to intermediate finance to firms with less access to financial resources (Petersen \& Rajan, 1997). As a consequence, suppliers would extend more credit to customers when the latter face greater difficulties in borrowing from banks, so that, for the receiving firm, trade and bank credit would be imperfect substitutes (Agostino \& Trivieri, 2014). The hypothesis of substitutability between bank and trade credit has been widely investigated. Nilsen (2002), by analyzing a sample of US manufacturing companies from the late 1950s to the early 1990 s, finds that the use of trade credit increased during monetary contractions. Atanasova and Wilson (2004) and Mateut et al. (2006) confirm this finding for a sample of UK manufacturing firms: during periods of tight monetary conditions, firms increased their reliance on interfirm credit to avoid bank credit rationing. Choi and Kim (2005) provide similar results for a sample of US-listed companies in the period 1975-1997. Garcia-Appendini and Montoriol-Garriga (2013), by analyzing a supplier-client matched sample during the 2007-2009 financial crisis, show that the use of trade credit by constrained firms increased during this period. Similar findings are provided by Casey and O'Toole (2014). Using euro area firmlevel data since the recent financial crisis, the authors

\footnotetext{
${ }^{7}$ The advantage of suppliers over financial institutions varies depending on the type of goods the supplier sells and how much the customer transformed them. The advantage is more pronounced for suppliers selling differentiated goods as they are often tailored to the needs of few customers; by contrast, standardized inputs have a reference price that any lender could be able to obtain (Giannetti et al., 2011). In terms of transformation, instead, the less the goods have been transformed by the client, the greater the advantage the supplier has over financial institutions in finding an alternative buyer (Petersen \& Rajan, 1997).
} 
find that credit rationed firms were more likely to use and apply for trade credit during the financial downturn. McGuinness et al. (2018) further deepen this analysis by studying whether trade credit helped financially constrained SMEs survive the financial crisis. Examining a large sample of SMEs across 13 European countries over the period 2003-2012, they show that trade credit had a positive impact on firm survival because of an efficient redistribution effect from unconstrained to constrained SMEs.

Biais and Gollier (1997) proposed an alternative view of the link between bank and trade credit. As sellers have private information on buyers, the use of trade credit by the latter may translate into a signal of the firms' quality to financial intermediaries, thus mitigating adverse selection problems and credit rationing. From this perspective, trade credit and bank credit do not necessarily substitute each other, but might instead be complements. The hypothesis of complementarity between bank and trade credit, and the related signaling theory have been empirically tested by several studies. Cook (1999), using data on 352 Russian firms in 1995, finds that firms receiving trade credit are more likely to obtain access to bank loans. Garcia-Appendini (2011), for a sample of US small enterprises, shows that banks are more likely to lend to firms that have been granted trade credit by their suppliers and to firms that pay higher proportions of their trade credit debts on time. Atanasova (2012), analyzing a set of UK companies in the period 19982006, provides strong evidence that for firms with high agency costs, the use of trade credit facilitates the access to conventional bank loans. Agostino and Trivieri (2014) and Deloof and La Rocca (2015) confirm the signaling role of trade credit and the idea of complementarity between trade and bank financing for a sample of Italian SMEs, and Andrieu et al. (2018) extend the validity of these findings to all the European firms.

In this paper, we contribute to the literature on the link between trade credit and bank financing by focusing on the role played by the type of lending relationships built by firms. More specifically, we investigate whether the creation of closer and long-lasting lending relationships, i.e., the adoption of relationship lending technologies, significantly affects the use of trade credit by firms. In the following section, we briefly revise the main theories and findings on relationship lending.

\subsection{Information production and benefits of relationship lending}

Small business lending by financial intermediaries can be classified into two main lending technologies, which are employed to address either credit rationing or overlending problems: transactions-based lending and relationship lending (Berger and Udell, 2002). ${ }^{8}$ Under transactions-based lending, lending decisions are based on "hard" information that is relatively easily available at the time of loan origination. Under relationship lending, the lender bases its final decisions on proprietary information about the firm and its owner gathered through a variety of contacts over time. This "soft" information is obtained through the provision of loans, deposits, and other financial products, and through the analysis of the future prospects of the business. Additional information may also be gathered through contacts with other members of the local community, such as suppliers and customers, who may give specific information about the firm or general information about the business environment in which it operates (Ferri et al., 2019b). Importantly, the information obtained over time has a significant value beyond the firm's financial statements, collateral, and credit score, helping the relationship lender mitigate informational opacity problems better than transactions lenders. This soft information, moreover, may not be easily observed by others or transmitted to others, so it often remains proprietary to the loan officer who collected it.

Under relationship lending, the strength of the relationship between the lender and the borrower affects credit availability. Traditionally, empirical studies on this topic have adopted indirect measures of relationship lending: the length of the bank-firm relationship (i.e., the amount of time the bank has provided loans, deposits or other financial services to the firm), the exclusivity of the relationship in terms of the bank being the sole provider of bank financing to the firm, the share of credit granted by the firm's main bank, and the geographical distance between the firm's headquarter and the bank branch (Petersen \& Rajan, 1994; Sette \& Gobbi, 2015; Murro \& Peruzzi, 2019; Ferri et al.,

\footnotetext{
${ }^{8}$ Transactions-based lending technologies include financial statement lending, asset-based lending, and credit scoring (see Berger \& Udell 2002 for a complete analysis of all lending technologies).
} 
2019b). All these measures proxy for the ability of banks to accumulate soft information about borrowers: longer relationships allow banks to accumulate information over time; banks holding a larger share of credit have better access to private information about the borrower; firms located closer to a bank branch may be easier and cheaper to monitor (Sette \& Gobbi, 2015). Empirical studies on lending technologies are often consistent with the importance of strong relationships. Petersen and Rajan (1994) and Angelini et al. (1998) show that longer relationships improve firms' access to credit. Berger and Udell (1995) and Brick and Palia (2007) find that borrowers with longer relationships pay lower interest rates and face lower collateral requirements. Degryse and Ongena (2005) and Agarwal and Hauswald (2010) indicate that borrowers' transportation costs induce a negative relationship between distance and the level of interest rates. Cenni et al. (2015) show that the number of banking relationships the firm maintains is negatively associated with credit availability. Finally, Bartoli et al. (2013) and Cucculelli et al. (2019) provide evidence that the use of soft information under relationship lending technologies decreases the probability of firms to experience credit restrictions. A few papers have tested the impact of relationship lending on credit availability during the last financial crisis, by confirming the beneficial effect of this lending technology. More specifically, Sette and Gobbi (2015) and Bolton et al. (2016) find that relationship lenders offer more support than transactional lenders during a crisis: banks located closer to their borrowers, involved in longer relationships, and holding a larger share of credit, granted more loans than other banks. Similar results are provided by Beck et al. (2018), who show that relationship lending alleviates firms' credit constraints during a downturn, especially for small and opaque firms.

In this paper, we contribute to the literature on relationship lending by investigating whether firms maintaining stronger lending relationships with their main bank are characterized by a different use of trade credit as a source of external financing.

\subsection{Hypotheses}

The trade credit theories described above suggest that the financial benefits obtained by buyers in the supplier-buyer relationship are analogous to the benefits accrued to bank borrowers as shown in the relationship lending literature. Both suppliers and relationship lenders are more likely to extend credit when strong relationships exist and when the exchange of private information reduces moral hazard and adverse selection problems (Petersen and Rajan, 1994; 1997; Berger \& Udell, 2002; Giannetti et al., 2011). A few studies see, e.g., (McMillan \& Woodruff, 1999; Uchida et al., 2013) empirically tested the so-called "relationship lending hypothesis of trade credit" and demonstrated that trade creditors actually behave as relationship lenders. This evidence clearly supports the idea of similarity between the dynamic of trade credit and the one of relationship lending. Hence, we expect that firms relying on relationship lending are also more likely to use trade credit in their business transactions.

Two distinct mechanisms are expected to drive the positive link between relationship lending and the use of trade credit: the type of information used by the relationship lender/supplier (private information channel) and the ability of the borrowing firm to create close relationships (relational capital channel). Regarding the first channel, firms relying on relationship lending may be more likely to use trade credit as a source of financing because of the similar information used in the screening process. Firms that use to provide soft information to bank lenders may be more inclined to disclose private data also to suppliers, thus increasing their chances to receive trade credit. Even though the specific information acquired by suppliers may be different to the one obtained by bank lenders, we argue that in both cases it can be classified as private information (i.e., information that is qualitative, not easily observed by others or transmitted to others). Suppliers can monitor and evaluate the production activity of the customer firms by visiting their premises and by analyzing the size and timing of their orders (Smith, 1987; Biais \& Gollier, 1997; Giannetti et al., 2011). In the same vein, financial intermediaries can acquire private information about the borrowing firms through frequent contacts over time and by providing them other financial products and services (Berger \& Udell, 1995; Ferri et al., 2019b). As for the second channel, firms with strong relationships with bank lenders may use more trade credit because of their propensity and ability to create valuable 
relationships with business parties (Kranton \& Minehart, 2001; Uchida et al., 2013). By exploiting their relational abilities, firms may create strong lending relationships with banks and suppliers, thus improving their financing opportunities. Santikian (2014) uses hand-collected data from a mid-sized bank in the USA and demonstrates that firms with greater relational abilities rely more on relationship lending, by enjoying closer and longer banking relationships. The firm's relational capital also matters for trade credit availability. McMillan and Woodruff (1999) show that trade credit is more likely to be extended by a supplier when the length of the relationship with the customer is longer and the customer belongs to a social or business network. Similarly, Kong et al. (2020) suggest that the access to trade credit significantly improves when customers have strong social connections with either suppliers or other companies.

Given this framework, we test the following hypotheses:

H1. Firms maintaining strong lending relationships are characterized by a higher use of trade credit as a source of external financing.

$\mathrm{H} 2$. The positive link between relationship lending and the use of trade credit is driven by the adoption of private information in both screening processes (private information channel).

H3. The positive link between relationship lending and the use of trade credit is driven by the relational ability of the borrowing firm (relational capital channel).

\section{Data and method}

\subsection{Data sources}

To perform our empirical investigation, we draw information from two main sources: (i) the Survey on Italian Manufacturing Firms (SIMF), carried out by UniCredit (and previously by MedioCredito Centrale - Capitalia), and (ii) the BvD-AIDA database. The Survey on Italian Manufacturing Firms provides detailed information about companies' relationships with their banks, market structure, export and internationalization activities, investments in innovation, ownership and governance structures, and workforce characteristics. The dataset includes a representative sample of manufacturing companies with 10-500 employees and the universe of manufacturing firms with more than 500 employees. $^{9}$ We use four waves of the survey covering the following 3-year periods: 1995-1997, 1998-2000, 2001-2003, 2004-2006. Each of the waves gathers information on approximately 4500 firms, representing about $9 \%$ of the population in terms of employees and $10 \%$ in terms of value added. To all the surveyed firms, we attach balance-sheet data provided by BvD-AIDA, the most comprehensive and widely-used source of financial information for public and private enterprises in Italy.

Table 1 reports a detailed description of all the variables employed in the empirical analysis. Table 2 provides summary statistics. At the average, the surveyed firms have been in business for 26 years and have more than 11 million $€$ in total sales; beyond $50 \%$ of companies have fewer than 35 employees, and below $5 \%$ of them have more than 500 workers; $1.2 \%$ of firms are listed in the stock market and $23.4 \%$ belong to a business group. The majority of firms are located in the North of Italy $(68.3 \%)$, while $18.2 \%$ of companies operate in the Center and $13.5 \%$ in the South of the country.

\subsection{Variable definitions}

\subsubsection{The use of trade credit}

Following previous studies (Giannetti et al., 2011; McGuinness et al., 2018), we quantify the use of trade credit by focusing on the volume extended by suppliers as reported in firms' balance-sheets. More specifically, we measure trade credit extended by suppliers as the ratio of accounts payables to total assets (Accounts Payable/Total Assets) and accounts payables to total loans (Accounts Payable/Total Loans) as robustness test.

Table 2 gives a baseline indication of the relevance of trade credit for the firms in our sample. The amount owed to suppliers represents, on average, $19.6 \%$ of total assets and $31.2 \%$ of total loans.

\footnotetext{
${ }^{9}$ Firms with $10-500$ employees are selected with a stratified sample method each time with a rotating panel scheme; therefore, only few of them appear in two consecutive waves.
} 


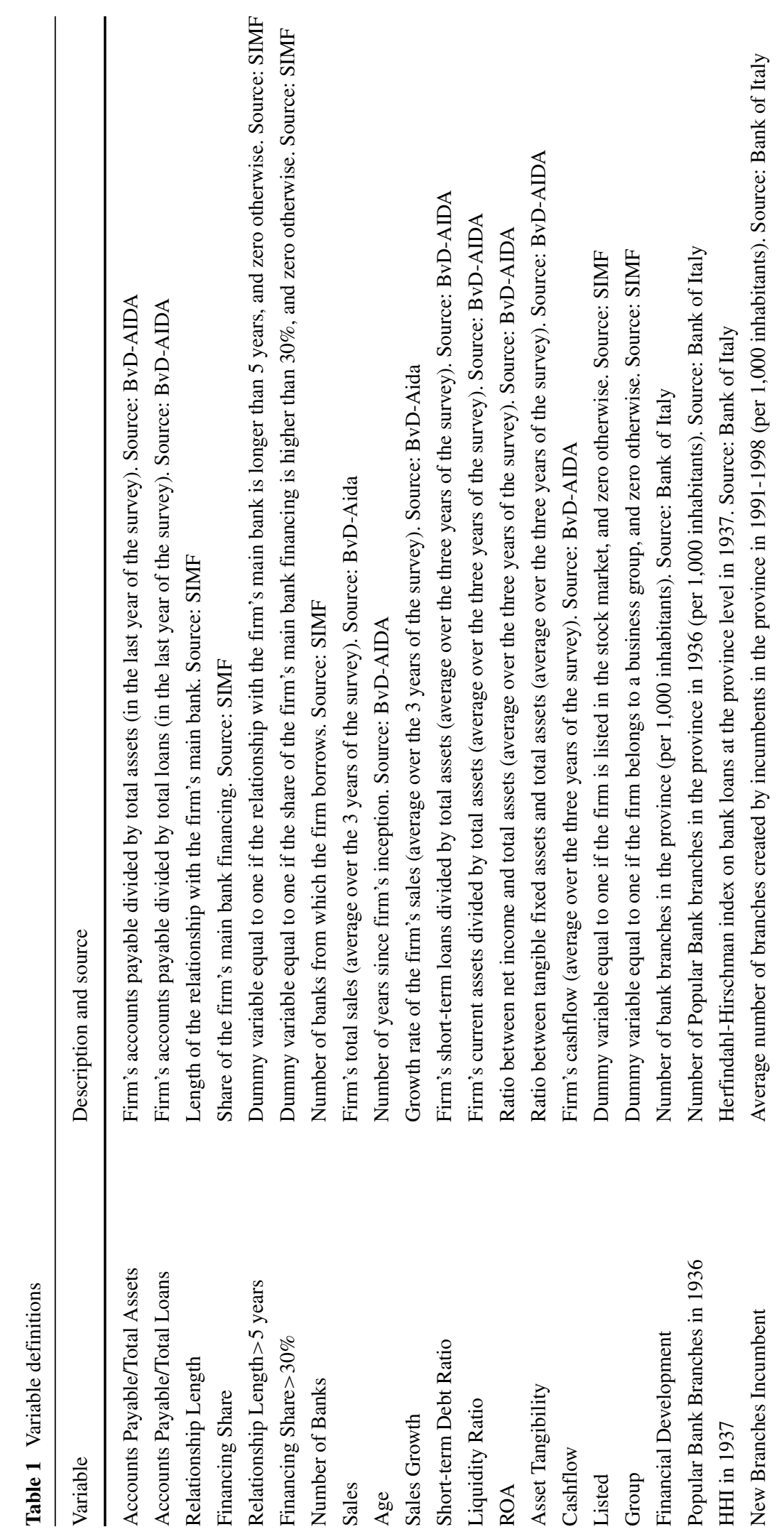




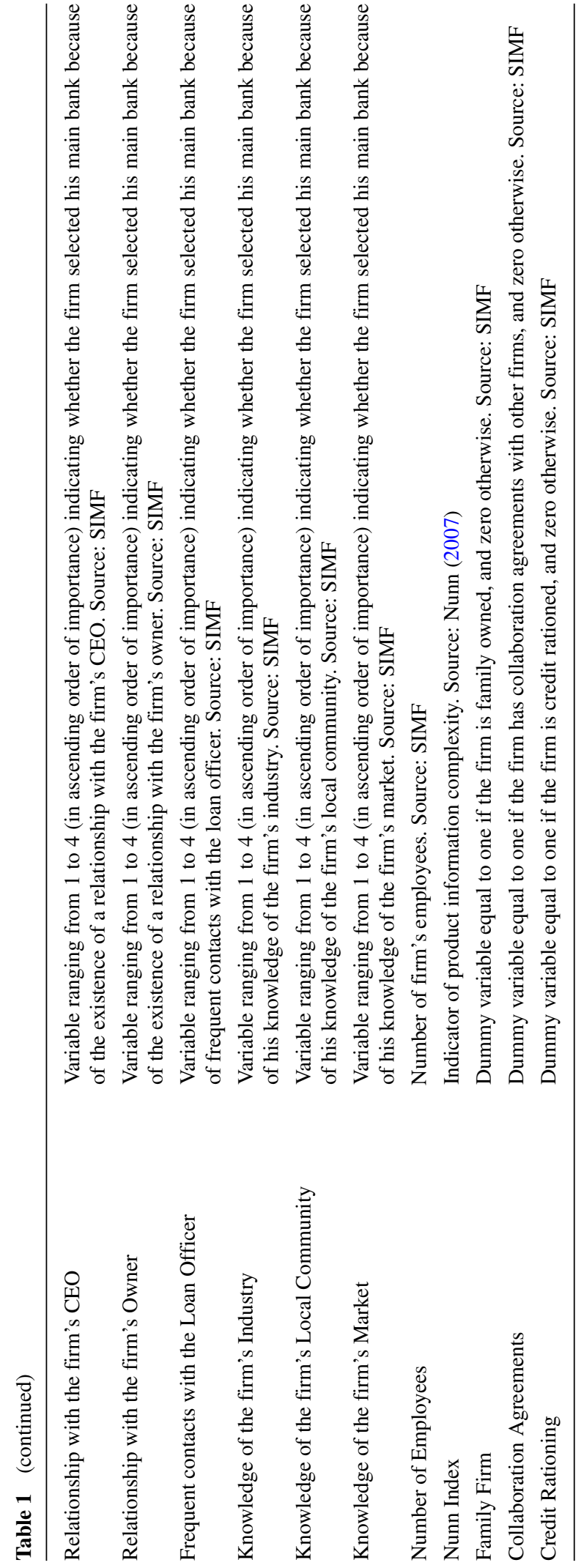


Table 2 Summary statistics

\begin{tabular}{|c|c|c|c|c|}
\hline & Obs. & Mean & Median & Std. Dev. \\
\hline \multicolumn{5}{|l|}{ Dependent variables: } \\
\hline Accounts Payable/Total Assets & 15,331 & 0.196 & 0.193 & 0.168 \\
\hline Accounts Payable/Total Loans & 15,331 & 0.312 & 0.316 & 0.254 \\
\hline \multicolumn{5}{|l|}{ Relationship lending variables: } \\
\hline Relationship Length & 16,005 & 16.65 & 15.00 & 11.94 \\
\hline Financing Share & 10,856 & 0.391 & 0.300 & 0.234 \\
\hline Relationship Length $>5$ years & 16,005 & 0.881 & 1.000 & 0.323 \\
\hline Financing Share $>30 \%$ & 10,856 & 0.659 & 1.000 & 0.474 \\
\hline Number of Banks & 17,262 & 5.445 & 5.000 & 3.638 \\
\hline \multicolumn{5}{|l|}{ Control variables: } \\
\hline Sales (thousands $€$ ) & 15,747 & 11,456 & 1,587 & 64,793 \\
\hline Number of Employees & 15,129 & 80.76 & 34.67 & 108.28 \\
\hline Total Assets (thousands €) & 15,331 & 33,682 & 6,672 & 176,134 \\
\hline Age & 17,405 & 26.61 & 22.00 & 20.72 \\
\hline Sales Growth & 15,692 & 0.072 & 0.053 & 0.214 \\
\hline Short-term Debt Ratio & 15,747 & 0.281 & 0.228 & 0.254 \\
\hline Liquidity Ratio & 15,747 & 0.712 & 0.732 & 0.166 \\
\hline ROA & 15,747 & 0.054 & 0.054 & 1.169 \\
\hline Asset Tangibility & 15,747 & 0.283 & 0.263 & 0.166 \\
\hline Cashflow (thousands $€$ ) & 15,743 & 127,887 & 963 & 281,038 \\
\hline Listed & 17,541 & 0.012 & 0.000 & 0.109 \\
\hline Group & 17,647 & 0.234 & 0.000 & 0.424 \\
\hline Financial Development & 17,119 & 0.559 & 0.573 & 0.175 \\
\hline \multicolumn{5}{|l|}{ Instrumental variables: } \\
\hline Popular Bank Branches in 1936 & 17,690 & 0.698 & 0.586 & 0.499 \\
\hline HHI in 1937 & 17,307 & 0.252 & 0.206 & 0.144 \\
\hline New Branches Incumbent & 17,690 & 23.87 & 16.31 & 25.09 \\
\hline \multicolumn{5}{|l|}{ Other variables: } \\
\hline Relationship with the firm's CEO & 1541 & 2.833 & 3.000 & 1.072 \\
\hline Relationship with the firm's Owner & 1541 & 2.624 & 3.000 & 0.992 \\
\hline Frequent contacts with the Loan Officer & 1541 & 2.641 & 3.000 & 0.978 \\
\hline Knowledge of the firm's Industry & 1541 & 2.619 & 3.000 & 0.951 \\
\hline Knowledge of the firm's Local Community & 1541 & 2.530 & 3.000 & 0.945 \\
\hline Knowledge of the firm's Market & 1541 & 2.628 & 3.000 & 0.984 \\
\hline Nunn Index & 13,991 & 0.663 & 0.716 & 0.216 \\
\hline Family Firm & 17,153 & 0.733 & 1.000 & 0.442 \\
\hline Collaboration Agreements & 12,417 & 0.055 & 0.000 & 0.227 \\
\hline Credit Rationing & 16,571 & 0.038 & 0.000 & 0.190 \\
\hline \multicolumn{5}{|l|}{ Geographical areas: } \\
\hline North & 17,474 & 0.683 & 1.000 & 0.465 \\
\hline Center & 17,474 & 0.182 & 0.000 & 0.386 \\
\hline South & 17,474 & 0.135 & 0.000 & 0.342 \\
\hline
\end{tabular}


Figure 1a draws the distribution of trade credit use across Italian provinces for the firms in our sample. The map indicates that the use of trade credit is not concentrated in few provinces: although companies located in the North of Italy seem to rely more on trade credit, we still find a high share of accounts payable on total assets in some Southern provinces.

\subsubsection{Relationship lending}

Consistently with the current literature on lending technologies (see Section 3.2), we use the information provided by the Survey on Italian Manufacturing Firms to create two main measures of relationship lending: (i) the length of the firm's main credit relationship (Relationship Length, expressed in logarithm), and (ii) the financing share of the firm's main bank (Financing Share). As the strength of the bankfirm relationship can vary non-continuously with the length of the lending relationship and the financing share of the firm's main bank, we employ two additional measures of relationship lending, directly built from our baseline indicators: (i) relationship length $>5$ years, a dummy variable equal to one if the relationship with the firm's main bank is longer than 5 years, and zero otherwise, and (ii) financing share $>30 \%$, a dummy variable equal to one if the financing share of the firm's main bank is higher than $30 \%$, and zero otherwise. Finally, we use the number of banking relationships enjoyed by the surveyed firm (Number of Banks) as a further proxy of relationship lending. ${ }^{10}$

Table 2 reports the summary statistics for all these variables. The average financing share of the firms' main bank is $39.1 \%$, the average number of banking relationships enjoyed by the sample firms is slightly more than 5 , and the length of their main lending relationship is more than 16 years. In addition, $88.1 \%$ of companies have a lending relationship that have lasted for more than 5 years and almost $66 \%$ of firms are financed by their main bank for more than $30 \%$ of total loans. Figure $1 \mathrm{~b}$ and $\mathrm{c}$ draw the distribution of our relationship lending measures across Italian provinces. The maps indicate that the

\footnotetext{
${ }^{10}$ While the first four variables (Relationship Length, Financing Share, Relationship Length $>5$ years and Financing Share $>30 \%$ ) are increasing in the level of relationship lending, the number of banking relationships is negatively associated with the relevance of relationship lending for the surveyed firms.
}

relevance of relationship lending is almost homogeneously widespread in the North, Center, and South of Italy, suggesting that it is not affected by the level of financial and economic development.

\subsubsection{Control variables}

To correctly identify the impact of relationship lending on the use of trade credit and to mitigate the omitted variables concern associated with the cross-sectional structure of our dataset, we control for a large set of possible confounding effects.

As primary controls, we include a set of firm-specific characteristics. The current literature (Petersen and Rajan, 1997; Deloof \& La Rocca, 2015) suggests that larger, older, and growing firms obtain more credit from suppliers. Hence, in our regressions we control for firm size, measured by the level of sales (Sales, expressed in logarithm), age (Age, expressed in logarithm), and growth, measured by the growth rate of the firm's sales (Sales Growth). Firms' credit quality may also be relevant in determining the use of trade credit. Although high-quality borrowers may not need payment delays, customers' credit quality positively affects the probability to obtain credit from suppliers (Petersen and Rajan, 1997). ${ }^{11}$ In line with this view, we include a set of balance-sheet indicators measuring the firm's creditworthiness. First, we include the firm's debt and liquidity ratios (Short-term Debt Ratio, computed as short-term loans divided by total assets; Liquidity ratio, computed as current assets divided by total assets), which account for the firm's financial position. Second, to measure his repayment ability, we control for a profitability indicator, the return on assets (ROA, computed as note income divided by total assets). Finally, as firms with more fixed assets may use them as collateral guarantees in their banking relationships, we include a tangibility indicator (Asset Tangibility, computed as tangible fixed assets divided by total assets). Companies that can rely on alternative financing sources use less trade credit in their commercial transactions (Cosci et al., 2020). For this reason, we control for the firm's level of internal capital (Cashflow, expressed in logarithm) and two

\footnotetext{
${ }^{11}$ The explicit price of trade credit does not appear to vary with the customer's credit quality, as customers in an industry get standard trade credit terms (Smith, 1987). If suppliers do not use prices to discriminate higher and lower-quality borrowers, they must use quantity restrictions.
} 


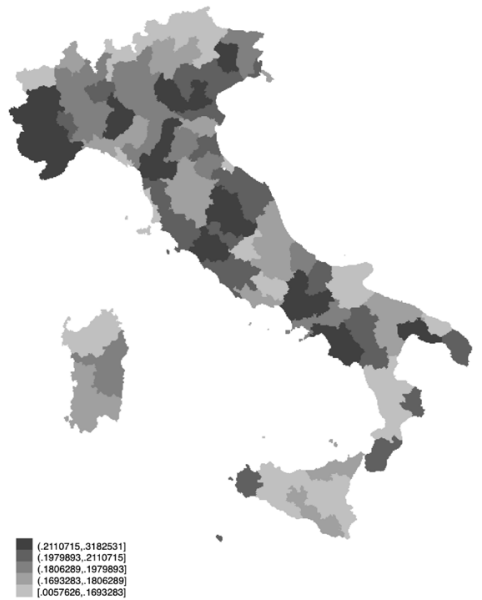

(a) Accounts Payable/Total Assets

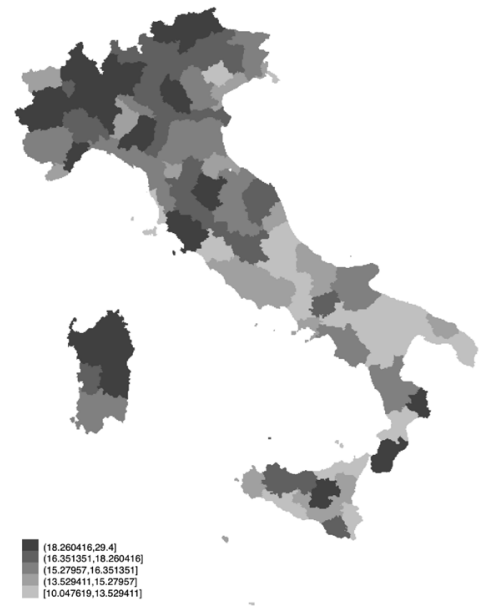

(b) Relationship Length

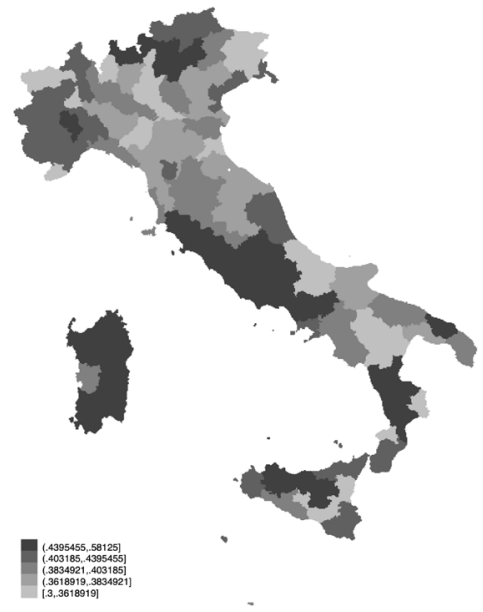

(c) Financing Share

Fig. 1 Relationship lending and the use of trade credit across Italian provinces

additional variables: Listed, a dummy variable equal to one if the firm is listed in the stock market, and zero otherwise; and Group, a dummy variable equal to one if the firm belongs to a business group, and zero otherwise.

The amount of trade credit extended by suppliers can also be affected by the level of financial development (Cassia \& Vismara, 2009; Deloof \& La Rocca, 2015; Andrieu et al., 2018). In regions with more developed financial systems, suppliers have easier access to bank loans and can act as agents for financial intermediaries, by channelling short-term funds from financial institutions to their customers (PalacńSánchez et al., 2019). In line with this view, we include a widely-used proxy for local financial development (Financial Development), i.e., the number of bank branches in the province per 1000 inhabitants (D’Onofrio et al., 2019).

Finally, to fully control for industry, time and region-specific effects, we include sector (at the NACE 2-digit level), province (at the NUTS-3 level), and survey dummies.

\subsection{Econometric specification}

To study the impact of relationship lending on the use of trade credit, we estimate the following model:

$T C_{i}=\alpha+\beta R L_{i}+\gamma X_{i}+\delta Z_{i}+\epsilon_{i}$

where $T C_{i}$ indicates our measure of trade credit use, i.e., Accounts Payable/Total Assets; $R L_{i}$ denotes, alternatively, one of the relationship lending indicators described in Section 4.2.2; $X_{i}$ is a vector of exogenous covariates, as discussed in Section 4.2.3; $Z_{i}$ is a vector of industry, province and survey dummies; $\epsilon_{i}$ is the error term. ${ }^{12}$ Equation 1 is estimated by ordinary least squares. ${ }^{13}$

In testing the impact of relationship lending on the use of trade credit, we must account for possible endogeneity problems. First, unobserved factors can be correlated with both the amount of accounts payable and the strength of the bank-firm relationship. Second, trade credit use may affect firms' incentives to maintain close and exclusive lending relationships, that is, the causality may be reversed. To alleviate these possible concerns, we follow two ways. First, we run our baseline regressions on a matched sample of firms relying and not relying on relationship lending. Second, we complement OLS estimates with an instrumental variables approach. The set of instruments employed includes province-level proxies for

\footnotetext{
${ }^{12}$ While the dependent and independent variables are measured in the last year of the survey, control variables are computed as average values over the 3 years of the survey. The correlation matrix for dependent, independent and control variables is reported in Table 3.

${ }^{13}$ Although the dependent variable is truncated, Eq. (1) is estimated by OLS instead of a Tobit model because its distribution is non-normal (McMillan \& Woodruff, 1999; Giannetti et al., 2011). Estimates using a Tobit model are reported in Appendix Table 9.
} 


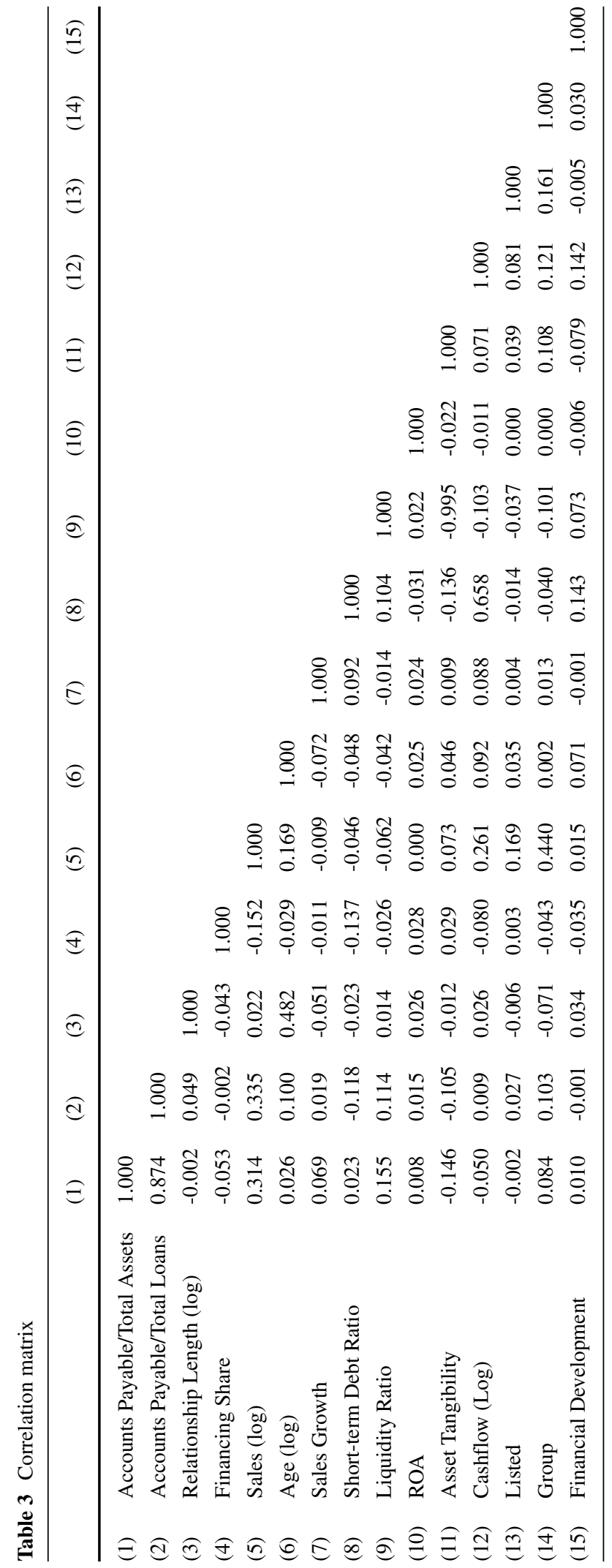


the tightness of the banking regulation introduced in Italy in 1936 and the following deregulation wave of the 1990s. As will be detailed, we expect these variables to be correlated with the strength of the bank-firm relationship but to affect the use of trade credit only through the relationship lending channel. ${ }^{14}$ We will further elaborate on both approaches in Section 5.2.

\section{Main results}

\subsection{Relationship lending and the use of trade credit}

Table 4 reports the estimation results about the impact of relationship lending on the use of trade credit. In columns (1)-(2), we employ our baseline measures of trade credit (Accounts Payable/Total Assets) and relationship lending (Relationship Length and Financing Share). In columns (3)-(7), as a robustness check, we use the alternative proxies for the use of trade credit and the strength of the lending relationship, as discussed in the previous section.

Starting with the baseline estimates, after controlling for various firm characteristics, industry, province and survey fixed effects, we find that relationship lending is positively associated with the use of trade credit. The estimated coefficients are 0.002 (statistically significant at 90\%) for the Relationship Length variable (column 1), and 0.013 (statistically significant at 90\%) for the Financing Share proxy (column 2 ). This suggests that a one standard deviation increase in the relationship's length increases the ratio between accounts payable and total assets by 0.16 percentage points, while a one standard deviation increase in the financing share of the firm's main bank is associated with an increase of 0.30 percentage points in the dependent variable. The results are similar when we measure the use of trade credit as the ratio between accounts payable and total loans. The estimated

\footnotetext{
${ }^{14}$ To further reduce the risk that our historical instruments have an independent effect (i.e., other than through relationship lending) on the use of trade credit, we included a proxy for current local financial development (the number of bank branches in the province) among the control variables (see Section 4.2.3).
}

coefficients are 0.008 (statistically significant at 99\%; column 3) and 0.043 (statistically significant at 99\%; column 4) for the Relationship Length and Financing Share variables, respectively. The positive association between relationship lending and the use of trade credit is still confirmed when we employ our alternative measures of relationship lending. Consistently with the baseline results, we find that the dummy variables Relationship Length $>5$ years and Financing Share $>30 \%$ are both positively and significantly associated with the amount of trade credit received (columns 5-6). The estimated coefficients suggest that firms with lending relationships longer than 5 years are associated with an increase in the ratio between accounts payable and total assets by 0.008 , while firms with a main bank's financing share larger than $30 \%$ are associated with an increase in the dependent variable by 0.010 . Regarding the number of banking relationships enjoyed by the firm, as reported in column 7, this variable results to be negatively associated with the use of trade credit, with an estimated coefficient of -0.002 (statistically significant at $99 \%$ ). As this variable is negatively associated with the relevance of relationship lending for the firm, the positive link between the strength of the lending relationship and the use of trade credit is further confirmed.

Regarding the control variables, estimation results are consistent with the evidence provided by the trade credit literature. First, firm size and firm growth result to be associated with a higher use of trade credit. As firm size can be considered a proxy of market power in the input market, it is reasonable to observe that suppliers lend more money to large customers (Petersen \& Rajan, 1997, Dess et al, 2015, Cosci et al., 2020. Firm's liquidity is also positively associated with the amount of accounts payable over total assets. As expected, the liquidity position of the company positively influences the willingness of suppliers to offer credit (Petersen \& Rajan, 1997). Finally, in line with our predictions, we find that firms that can rely on alternative financing sources use less trade credit in their commercial transactions: the estimated coefficients of the Cashflow, Listed, and Group variables are all negative and statistically significant.

Taking stock of these results, we can conclude that, consistently with Hypothesis 1, firms maintaining strong lending relationships are associated with an 


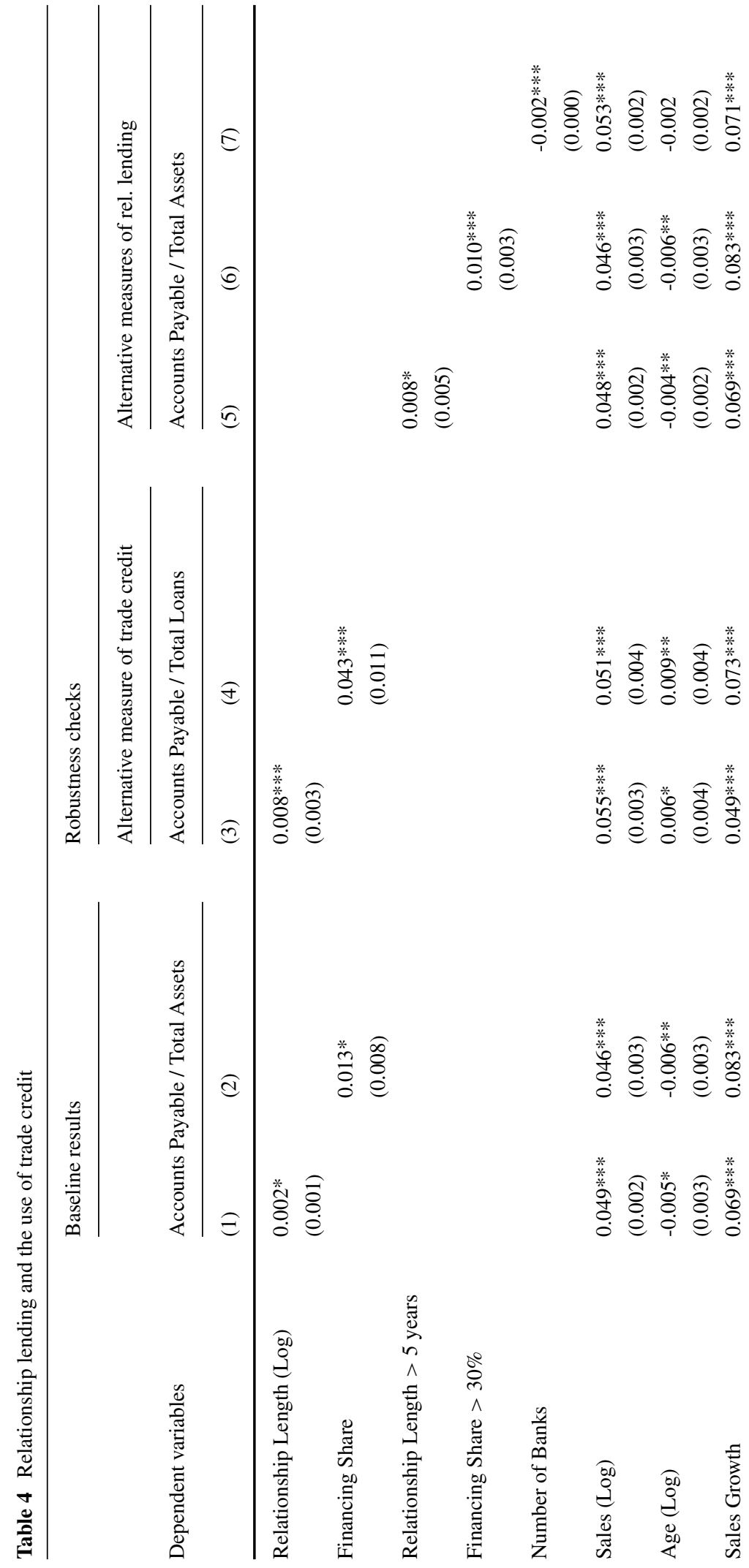




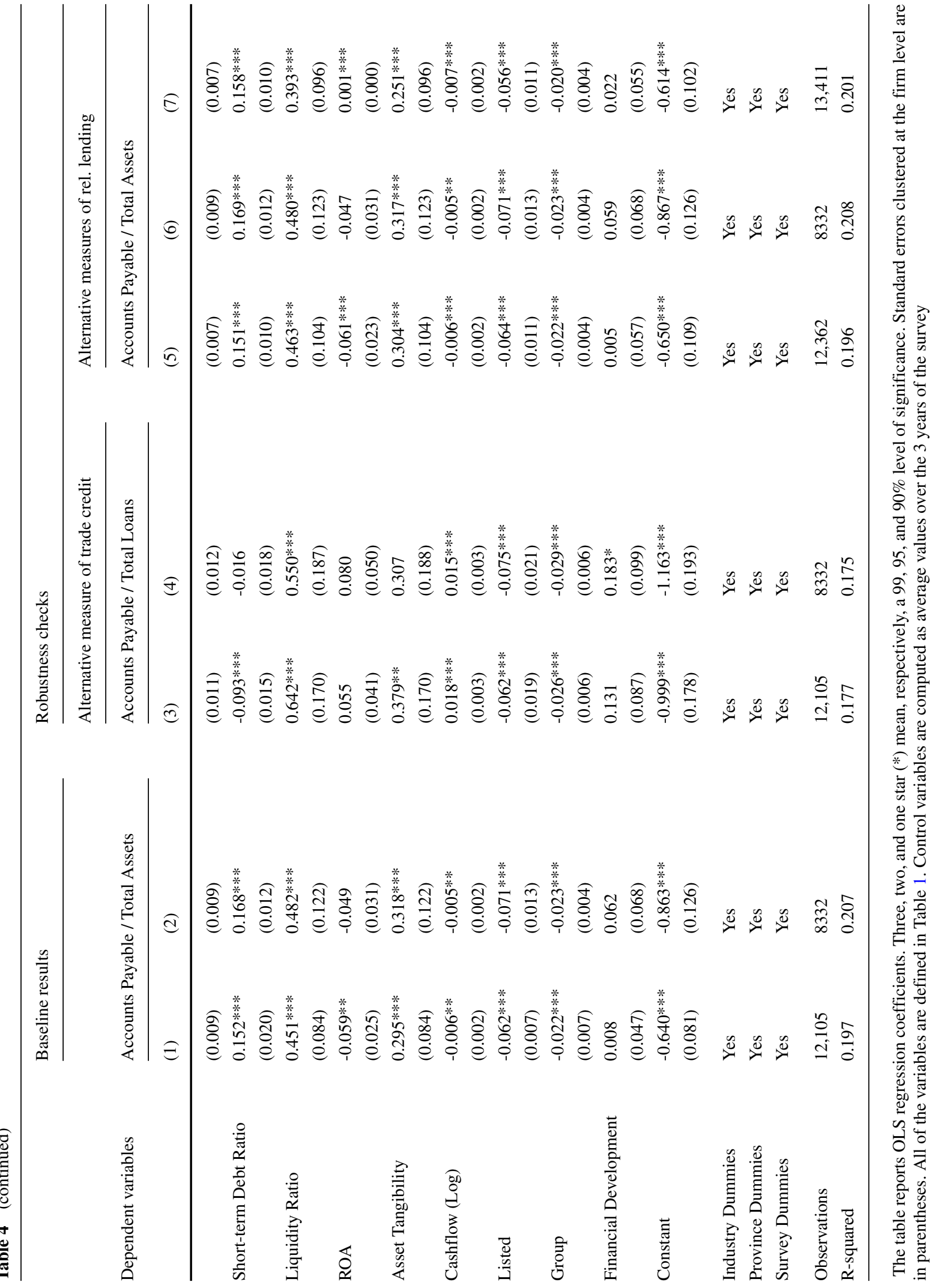


increasing use of trade credit as a source of external financing. 15

\subsection{Addressing endogeneity concerns}

The OLS estimates discussed above might be severely affected by endogeneity concerns. First, although in our regressions we control for a large set of factors that may drive the use of trade credit, it is still possible that some unobserved variables simultaneously affect the amount of accounts payable and the strength of the bank-firm relationship. Second, trade credit use may affect firms' incentives to maintain close and exclusive lending relationships, that is, the causality may be reversed. In this section, we address these concerns by employing a propensity score matching (PSM) approach and a 2SLS model with instrumental variables.

In order to follow the PSM approach, we first split the sample into two groups - firms with high levels of relationship lending and firms with low levels of relationship lending — on the basis of the dummy variables Relationship Length $>5$ years and Financing Share $>30 \%$. Then, we match the firms of the two groups so that the two subsamples are similar as possible in terms of the variables that might be correlated with the use of trade credit. More specifically, we estimate a probit model where the dependent variable is, alternatively, Relationship Length $>5$ years and Financing Share $>30 \%$. This probit regression includes all the firm-specific controls used in our baseline estimations ${ }^{16}$ and requires a tolerance level for the maximum propensity score distance (caliper) between the treatment and the control group equal to

\footnotetext{
${ }^{15}$ The reader could have expected to observe a negative association between relationship lending and trade credit use, due to the impact of strong banking relationships on credit availability. By improving access to bank financing, relationship lending could have reduced firms' need for trade credit, consistently with the theory of substitutability between bank and trade credit (see Section 3.1). Although this view is not confirmed in our framework, in Appendix B, we investigate the role played by credit rationing in shaping the link between relationship lending and trade credit use.

${ }^{16}$ The control variables included in the estimation are: Sales (Log), Age (Log), Sales Growth, Short-term Debt Ratio, Liquidity Ratio, ROA, Asset Tangibility, Cashflow (Log), Listed, Group, and Financial Development.
}

0.0001 (Fang et al., 2014; Murro \& Peruzzi, 2019). ${ }^{17}$ Once obtained the treatment and control groups, we end the procedure by rerunning our baseline regressions and robustness checks as in Eq. 1. Estimation results are reported in panel A of Table 5. In columns (1)-(2), we employ our baseline measures of trade credit (Accounts Payable/Total Assets) and relationship lending (Relationship Length and Financing Share), while in columns (3)--(7), we use the alternativve proxies for the use of trade credit and the strength of the lending relationship. The regression coefficients for the Relationship Length and Financing Share variables are still positive and statistically significant, both in the baseline (columns 1-2) and in the robustness checks estimations (columns 3-4), confirming the positive association between relationship lending and the use of trade credit. Regarding the alternative measures of relationship lending, we find that the dummy variable Financing Share $>30 \%$ is positively associated with the amount of trade credit received (column 6), while the number of banking relationships enjoyed by the firm results to be negatively associated with the use of trade credit (column 7), thus supporting our main findings.

The second approach we follow to mitigate the risk of omitted variables bias and reverse causality is based on the use of instrumental variables. Our strategy is to identify exogenous restrictions in the local financial system that affect the strength of lending relationships without directly influencing the use of trade credit by firms. To this end, we exploit the 1936 Italian Banking Law and the deregulation wave of the 1990s (Guiso et al., 2003; 2004; Herrera $\&$ Minetti, 2007). To understand the choice of our instruments, we first need to discuss the Italian banking regulation. In 1936 the Comitato Interministeriale per il Credito e il Risparmio (CICR) enacted strict norms for the entry of banks into local credit markets: from 1938 each credit institution could only open branches in an area of competence (one or multiple

\footnotetext{
${ }^{17}$ Figure 2 reports the kernel density of the estimated propensity score for the treated and control groups before and after the matching. The graphs indicate that matching strongly improves the degree of similarity between the two subsamples in terms of the covariates we use for the matching strategy. This confirms that the PSM procedure reduces the likelihood that omitted differences, rather than relationship lending, drive our results.
} 


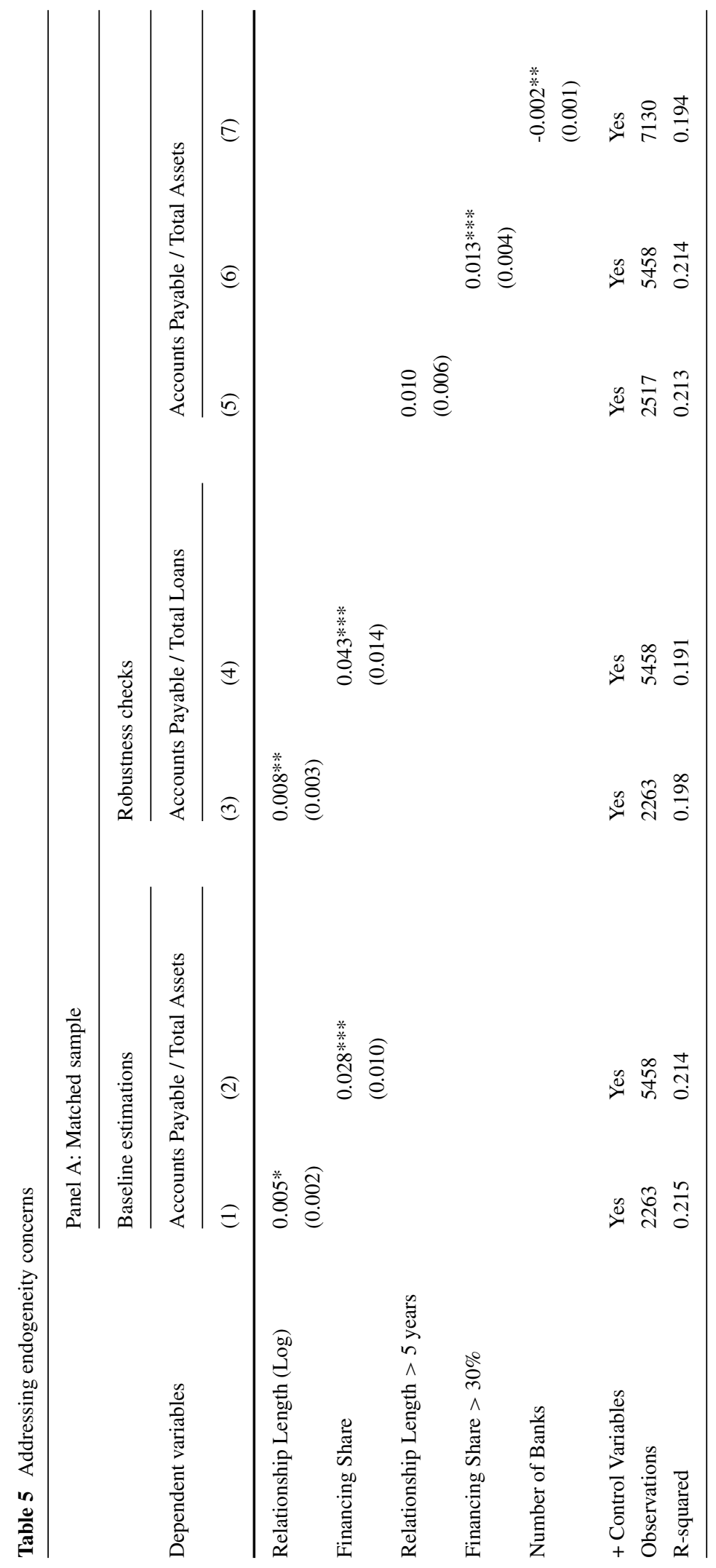




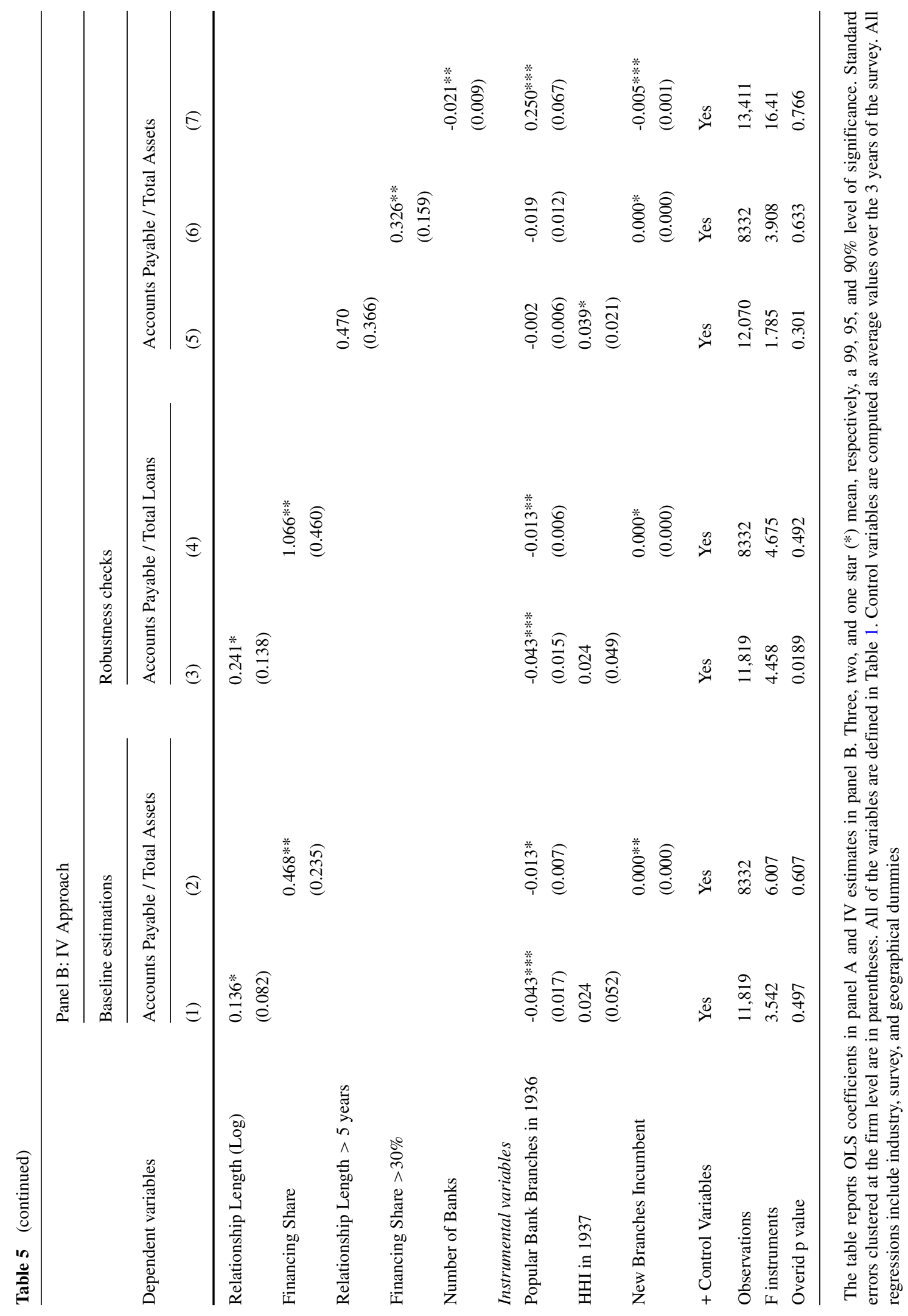


provinces) determined on the basis of its presence in 1936. Banks were also required to shut down branches outside their area of competence. While the regulatory prescriptions were uniform across Italy, the constrictiveness of the regulation varied across provinces and depended on the relative importance of different types of banks in the local market in 1936. For example, while savings and popular banks were less constrained by the regulation, cooperative banks were more strongly restricted. Guiso et al. (2004) demonstrate empirically that the 1936 regulation had a profound impact on the local supply of banking services (creation and location of new branches) and on the ability of firms to obtain credit. Herrera and Minetti (2007) indicate that the 1936 regulation and the following deregulation wave of the 1990s had a longlasting impact on the provincial banking structure, which lead to a substantial variation in the strength of credit relationships across Italian provinces. Following these studies, we use as instrumental variables the number of popular bank branches in the province in 1936 (Popular Bank Branches in 1936, per 1000 inhabitants), the Herfindahl-Hirschman index on bank loans at the province level in 1937 (that is the first available year), and the average number of new branches opened in the province by incumbent banks in the deregulation years, 1991-1998 (New Branches Incumbent, per 1000 inhabitants). ${ }^{18}$ To reduce the risk that these historical instruments have an independent effect on the use of trade credit, i.e., other than through relationship lending, we also control for current local financial development (Financial Development, see Section 4.2.3) in all the regressions. Estimation results of the 2SLS model are reported in panel B of Table 5. The regression coefficients for the Relationship Length and Financing Share variables are still positive and statistically significant, both in the baseline (columns 1-2) and in the robustness checks estimations (columns 3-4). More specifically, when we employ our baseline measure of trade credit (Accounts Payable/Total Assets), the estimated coefficients are 0.136 (statistically significant at $90 \%$; column 1) for the length of the lending relationship, and 0.468 (statistically significant at $95 \%$; column

\footnotetext{
${ }^{18}$ As these instruments are at the province level, in the 2SLS estimates we replace province fixed effects with area dummies.
}

2) for the financing share of the firm's main bank. The results are consistent with a positive association between relationship lending and the use of trade credit also when we adopt the alternative measures of relationship lending (columns 5-7). With the exception of the dummy variable Relationship Length $>5$ years, the regression coefficients of all the other independent variables are statistically significant and with the expected sign. To conclude, at the bottom of the table, we report the coefficients of our instrumental variables in the first stage estimates. ${ }^{19}$ Consistently with our expectations and previous studies (Guiso et al., 2003; 2004; Herrera \& Minetti, 2007), the strength of the lending relationship is decreasing in the number of popular bank branches in the province in 1936 and increasing in the number of new branches opened by incumbents in the 90 s.

\section{Disentangling the channels of influence}

\subsection{The multidimensional nature of lending relationships}

In order to get additional insights on the association between relationship lending and the use of trade credit, in this section we exploit a specific question included in the last wave of the SIMF, which provides detailed information about the firm's relationship with its main bank. The questionnaire reads as follows: "Which of these characteristics are key in selecting your main bank? (a) the bank has a relationship with the firm's CEO; (b) the bank has a relationship with the firm's owner; (c) the firm has frequent contacts with the loan officer; (d) the bank knows the firm's industry; (e) the bank knows the firm's local community; (f) the bank knows the firm's market". In answering the question, firms had to assign a weight, in ascending order of importance from 1 (not at all) to 4 (very much), to each characteristic.

Starting from these answers, we create six indicators of the nature of the lending relationship: Relationship with the firm's CEO, Relationship with the

\footnotetext{
${ }^{19}$ For reasons of space, first-stage regression results are provided in Table 10.
} 
firm's Owner, Frequent contacts with the Loan Officer, Knowledge of the firm's Industry, Knowledge of the firm's Local Community, Knowledge of the firm's Market. Then, following Berger and Udell (2002), we classify these relationship features as being more related to the relational ability of the firm ( $a$ and $b$ ) or to the provision of private information $(\mathrm{c}, \mathrm{d}, \mathrm{e}$, and f). ${ }^{20}$ As reported in Table 11 , almost $30 \%$ of the surveyed firms declare that the relationship between the bank and the firm's CEO is very important in the selection of the main bank. On the contrary, only $9.70 \%$ of firms consider the knowledge of the firm's market a relevant characteristic for choosing a bank.

In order to unbundle the multidimensional nature of lending relationships and test the private information (Hypothesis 2) and relational capital (Hypothesis 3) channels, we estimate our regressions by replacing the baseline measures of relationship lending with the new indicators. Estimation results are reported in Table 6. As can be noted, almost all the indicators are significantly related with our main dependent variable. More specifically, the indicators related to the relational ability of the firm are positive and statistically significant in explaining the use of trade credit. The estimated coefficients are 0.014 (statistically significant at $99 \%$ ) for both variables. As for the measures related to the provision of private information, the Frequent contacts with the Loan Officer, the Knowledge of the firm's Industry, and the Knowledge of the firm's Local Community variables are significantly correlated with the amount of accounts payable over total assets. By contrast, the coefficient of the last variable (Knowledge of the firm's Market) is positive but not statistically significant. ${ }^{21}$ These findings suggest

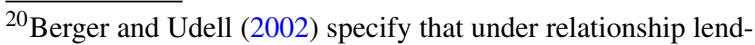
ing "the lender bases its decisions in substantial part on proprietary information about the firm and its owner gathered through a variety of contacts over time. [...] Additional information may also be gathered through contact with other members of the local community, such as suppliers and customers, who may give specific information about the firm and owner or general information about the business environment in which they operate".

${ }^{21}$ These results remain statistically significant when we run our regressions on the subsample of firms characterized by stronger lending relationships, i.e., firms with a lending relationship longer than 5 years.
}

that the positive association between relationship lending and the use of trade credit is driven by both the relational capital and private information channels.

\subsection{The role of private information and firms' relational capital}

The results discussed in the previous section suggest that the positive association between relationship lending and the use of trade credit is driven by both the private information and relational capital channels, as predicted by Hypotheses 2 and 3. However, those findings are based only on the last wave of the SIMF, which is the only wave asking firms additional information about their banking relationships. In this section, we aim to test the validity of Hypotheses 2 and 3 for the whole sample of firms and investigate whether relationship lending affects differently the use of trade credit depending on the level of firms' information opacity and relational capital. In particular, we argue that, if the private information channel works, we should observe a positive and statistically significant association between relationship lending and the use of trade credit for more opaque firms (Hypothesis 2). Similarly, if the relational capital channel is in place, we expect to find a positive and statistically significant correlation between relationship lending and the amount of accounts payable over total assets for companies with higher relational abilities (Hypothesis $3)$.

Starting with the role played by private information, in Table 7, we test Hypothesis 2 by splitting our sample based on the level of firm's information opacity. Following Ferri et al. (2019a), we use two measures to distinguish between informationally opaque and informationally transparent companies: firm size, proxied by the number of employees, and the Nunn Index, an indicator of product information complexity (Nunn, 2007). ${ }^{22}$ Starting with firm size, the results

\footnotetext{
$\overline{{ }^{22} \text { Nunn (2007) }}$ employs data from the US input-output tables to measure the information specificity of traded goods. Goods whose inputs are not sold on an organized exchange are classified as more informationally complex. In line with Ferri et al. (2019a) and Minetti et al. (2021a), we apply the Nunn index to our sample firms on the basis of their NACE classification.
} 
Table 6 The multidimensional nature of lending relationships

Dependent variables Accounts Payable / Total Assets

(1)

$0.014 * * *$

(0.005)

Relationship with the firm's Owner

Frequent contacts with the Loan Officer

Knowledge of the firm's Industry

Knowledge of the firm's Local Community

Knowledge of the firm's Market

+ Control Variables

Industry Dummies

Province Dummies

Observations

R-squared

(2)

(3)

(4)

$(5)$

(6)

$0.014 * * *$
$(0.005)$

$0.011 * *$

(0.005)

$0.012 * *$

(0.005)

$0.010 * *$

(0.005)

0.008

(0.005)

$\begin{array}{llllll}\text { Yes } & \text { Yes } & \text { Yes } & \text { Yes } & \text { Yes } & \text { Yes } \\ \text { Yes } & \text { Yes } & \text { Yes } & \text { Yes } & \text { Yes } & \text { Yes } \\ \text { Yes } & \text { Yes } & \text { Yes } & \text { Yes } & \text { Yes } & \text { Yes } \\ 1188 & 1188 & 1188 & 1188 & 1188 & 1188 \\ 0.107 & 0.106 & 0.104 & 0.105 & 0.103 & 0.102\end{array}$

The table reports OLS coefficients. Regressions are run only on the last wave of the survey (2004-2006). Three, two, and one star (*) mean, respectively, a 99, 95, and 90\% level of significance. Standard errors clustered at the firm level are in parentheses. All of the variables are defined in Table 1. Control variables are computed as average values over the 3 years of the survey

reported in panel A of Table 7 indicate that relationship lending is positively and significantly associated with the use of trade credit only for the subsample of small and medium-sized enterprises (columns 1-2). Regression coefficients for the Relationship Length and Financing Share variables are 0.002, statistically significant at $90 \%$, and 0.022 , statistically significant at $99 \%$, respectively. The results are similar when we employ the Nunn index as a measure of firm's information opacity. ${ }^{23}$ As shown in panel B of Table 7 ,

\footnotetext{
${ }^{23}$ In Table 12, we test the robustness of these results by employing two alternative measures of firm size (sales and total assets) and an additional proxy of firm opacity, that is the listed status of the company. Estimation results support our main findings: relationship lending is positively and significantly associated with the use of trade credit for the subsamples of firms suffering more from information asymmetries, i.e., small firms and unlisted companies.
}

relationship lending is positively and significantly correlated with the amount of accounts payable over total assets only for the subsample of firms with informationally complex products (columns 1-2). Although the regression coefficient of the Relationship Length variable is not statistically significant, the one of the Financing Share proxy is equal to 0.017 statistically significant at $90 \%$. Overall, these results indicate that the positive association between relationship lending and the use of trade credit is statistically significant only for those companies that suffer more from information opacity and for which the provision of private information is more valuable. Hence, the private information channel seems to work in our framework and Hypothesis 2 is confirmed.

The validity of Hypothesis 3 is tested in Table 8, where sample firms are classified on the basis of their relational ability. Several studies have shown that 
Table 7 The role of private information

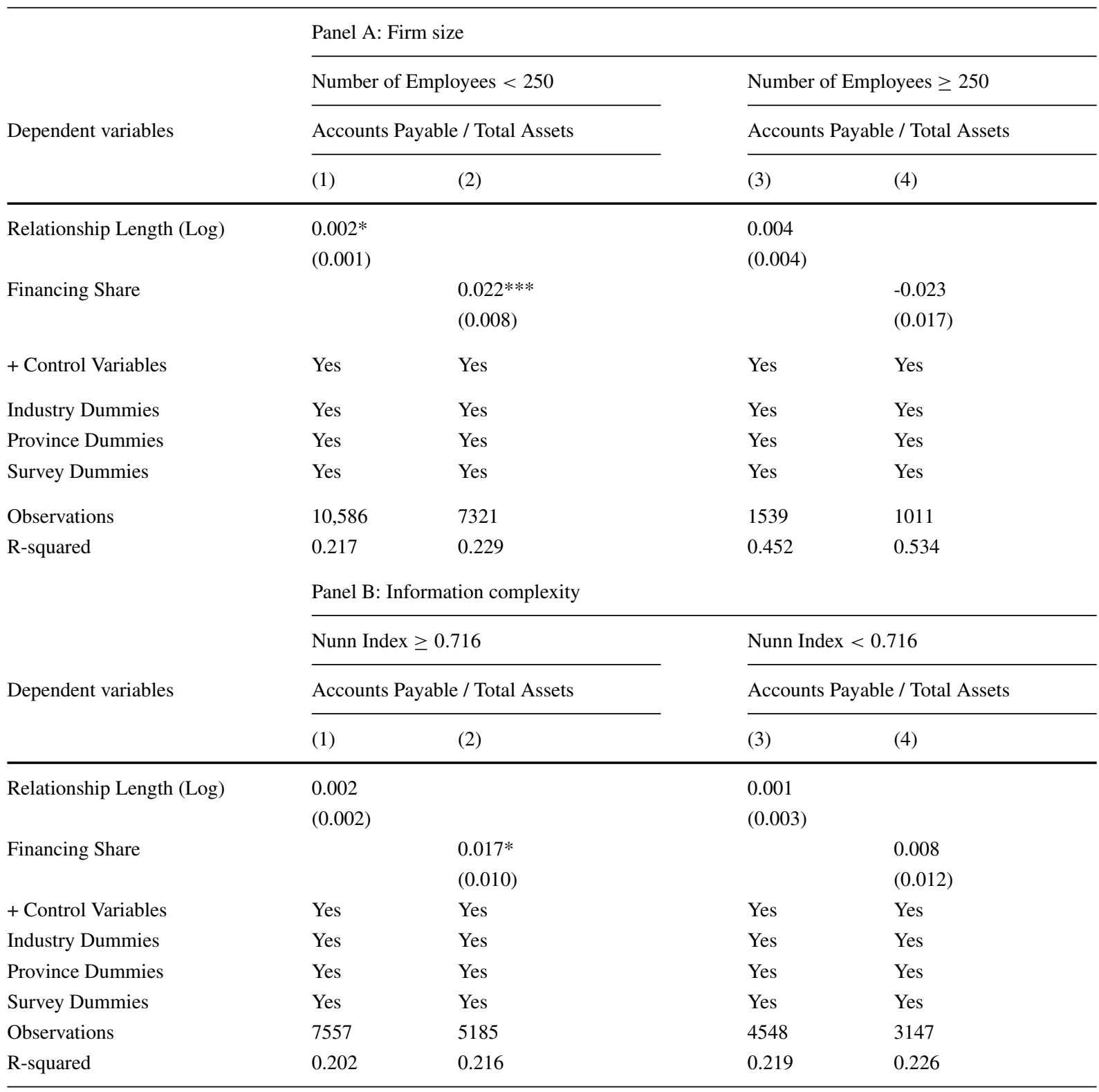

The table reports OLS coefficients. Three, two, and one star (*) mean, respectively, a 99, 95, and 90\% level of significance. Standard errors clustered at the firm level are in parentheses. In panel A, firms are classified as having less (columns 1-2) or more (columns 3-4) than 250 employees, the threshold used by the European Commission to define small and medium-sized enterprises. In panel B, firms are classified as having a Nunn Index higher (columns 1-2) or lower (columns 3-4) than 0.716, the median value of the sample. All of the variables are defined in Table 1. Control variables are computed as average values over the 3 years of the survey

family owned firms invest larger amounts of resources in nurturing interpersonal relationships in comparison to non-family owned businesses (Salvato and Melin, 2008; Amore \& Bennedsen, 2013; Peruzzi, 2017; Cucculelli et al., 2019). Hence, we use family owner- ship as first measure of relational capital. The Survey on Italian Manufacturing Firms asks each firm to indicate the type of the company's main shareholders. By relying on this information, we create the dummy variable Family Firm, which is equal to one if the 
Table 8 The role of firms' relational capital

\begin{tabular}{|c|c|c|c|c|}
\hline \multirow{4}{*}{ Dependent variables } & \multicolumn{4}{|c|}{ Panel A: Firm ownership } \\
\hline & \multicolumn{2}{|c|}{ Family Firm = 1} & \multicolumn{2}{|c|}{ Family Firm $=0$} \\
\hline & \multicolumn{2}{|c|}{ Accounts Payable / Total Assets } & \multicolumn{2}{|c|}{ Accounts Payable / Total Assets } \\
\hline & (1) & (2) & (3) & (4) \\
\hline \multirow[t]{2}{*}{ Relationship Length (Log) } & \multicolumn{2}{|l|}{$0.003 *$} & \multicolumn{2}{|l|}{-0.003} \\
\hline & \multicolumn{2}{|l|}{$(0.002)$} & \multicolumn{2}{|l|}{$(0.003)$} \\
\hline \multirow[t]{2}{*}{ Financing Share } & & $0.018^{*}$ & \multirow{2}{*}{\multicolumn{2}{|c|}{$\begin{array}{l}0.005 \\
(0.012)\end{array}$}} \\
\hline & & $(0.009)$ & & \\
\hline + Control Variables & Yes & Yes & Yes & Yes \\
\hline Industry Dummies & Yes & Yes & Yes & Yes \\
\hline Province Dummies & Yes & Yes & Yes & Yes \\
\hline Survey Dummies & Yes & Yes & Yes & Yes \\
\hline Observations & 8692 & 5965 & 3166 & 2257 \\
\hline \multirow[t]{3}{*}{ R-squared } & 0.223 & 0.235 & 0.203 & 0.226 \\
\hline & \multicolumn{4}{|c|}{ Panel B: Collaboration Agreements } \\
\hline & Collabo & reements $=1$ & Collabo & greements $=0$ \\
\hline \multirow[t]{2}{*}{ Dependent variables } & \multicolumn{2}{|c|}{ Accounts Payable / Total Assets } & \multicolumn{2}{|c|}{ Accounts Payable / Total Asset } \\
\hline & (1) & (2) & (3) & (4) \\
\hline \multirow[t]{2}{*}{ Relationship Length (Log) } & \multicolumn{2}{|c|}{$0.003 * *$} & \multicolumn{2}{|l|}{0.001} \\
\hline & \multicolumn{2}{|l|}{$(0.001)$} & \multicolumn{2}{|l|}{$(0.002)$} \\
\hline \multirow[t]{2}{*}{ Financing Share } & & $0.062 * *$ & & 0.005 \\
\hline & & $(0.031)$ & & $(0.009)$ \\
\hline + Control Variables & Yes & Yes & Yes & Yes \\
\hline Industry Dummies & Yes & Yes & Yes & Yes \\
\hline Province Dummies & Yes & Yes & Yes & Yes \\
\hline Survey Dummies & Yes & Yes & Yes & Yes \\
\hline Observations & 474 & 375 & 8181 & 6081 \\
\hline R-squared & 0.391 & 0.296 & 0.194 & 0.203 \\
\hline
\end{tabular}

The table reports OLS coefficients. Three, two, and one star $\left(^{*}\right)$ mean, respectively, a 99, 95, and 90\% level of significance. Standard errors clustered at the firm level are in parentheses. In panel A, firms are classified as being family (columns 1-2) or non-family (columns 3-4) owned. In panel B, firms are classified as having collaboration agreements (columns 1-2) or not (columns 3-4). All of the variables are defined in Table 1 . Control variables are computed as average values over the 3 years of the survey

firm's main shareholder is an individual or a family and zero otherwise, and classify sample firms as being family or non-family owned. The second measure of relational capital we employ in our estimations is the existence of collaboration agreements among the surveyed firm and other businesses. In line with the current literature (Cousins et al., 2006; Hormiga et al., 2011), we argue that firms with greater relational abilities are more likely to engage in these kind of contracts. The Survey on Italian Manufacturing Firms provides information about the existence of such collaborations and allows us to create a dummy variable, 
Collaboration Agreements, which is equal to one if the firm is engaged in these contracts and zero otherwise. $^{24}$ The estimation results are reported in Table 8. Starting with family ownership (panel A), the regression coefficients indicate that relationship lending is positively and significantly associated with the use of trade credit only for the subsample of family owned firms (columns 1-2). The estimated coefficients of our independent variables are 0.003 statistically significant at $90 \%$ for Relationship Length, and 0.018 statistically significant at $90 \%$ for Financing Share. The results are quite similar when we employ the existence of collaboration agreements as a measure of firms' relational capital. As shown in panel B, relationship lending is positively and significantly correlated with the amount of accounts payable over total assets only for the subsample of firms involved in collaboration agreements (columns 1-2). The regression coefficients are 0.003 , statistically significant at $95 \%$ for the length of the lending relationship, and 0.062, statistically significant at $95 \%$ for the financing share of the firm's main bank. Overall, these findings suggest that the positive correlation between relationship lending and the amount of trade credit is statistically significant only for those companies that have more relational ability. Hence, the relational capital channel is at work and Hypothesis 3 is confirmed.

\section{Conclusions}

This paper investigated the impact of relationship lending on the amount of trade credit granted by suppliers. By relying on the Survey on Italian Manufacturing Firms, we found that firms maintaining close and long-lasting relationships with their main banks are associated with a higher use of trade credit as source of financing. This finding is robust to alternative measures of relationships lending and trade credit, and to different estimation techniques, which partially accounted for endogeneity concerns. We also investigated the mechanisms driving the positive link between relationship lending and the use of trade credit. More specifically, we expected two

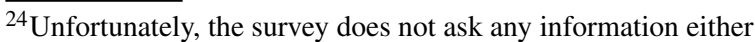
about the type of the collaboration or about the companies involved.
}

main channels being in place: the private information channel and the relational capital channel. Regression results confirmed our expectations. First, firms relying on relationship lending are associated with a larger use of trade credit because of the similar information used in the screening process. Firms that use to provide soft information to bank lenders, usually more opaque firms, are more inclined to disclose private data also to suppliers, thus increasing their chances to receive trade credit. As for the second channel, we provide evidence that firms characterized by greater relational abilities obtain larger amounts of trade credit from their suppliers.

In providing this evidence, we contributed to the finance literature on the link between trade credit and bank financing. To the best of our knowledge, we are the first highlighting the relevance of private information and firms' relational capital in shaping the link between relationship lending and the amount of trade credit extended by suppliers. This result not only sheds light on the dynamics of trade credit provision, but is also particularly important from a policy and managerial point of view. First, in a policy perspective, our findings reveal a need for banking regulation and supervision to encompass banking business models in evaluating banks (Minetti et al., 2021b). The current approach might not be suitable for small local banks investing in relationship lending and soft information acquisition and could weaken SMEs' chances to receive both bank financing and trade credit from suppliers. Second, from a managerial point of view, our results uncover the relevance of firms' ability to create strong relationships with banks, suppliers, and other companies, that may help alleviating financial constraints by improving the availability of trade credit and bank financing.

Finally, we acknowledge that the analysis carried out in this paper would benefit from a larger time span including the most recent years, as this would give us the opportunity to investigate the link between relationship lending and trade credit also during the last financial crisis. Moreover, additional information about suppliers would be extremely useful to better understand the dynamic of trade credit provision and the role played by both soft information and firms' relational capital. Unfortunately, the lack of these data makes these prospects an assignment for future research. 


\section{Appendix A: Additional tables and figures}

\section{Balancing test for PSM}

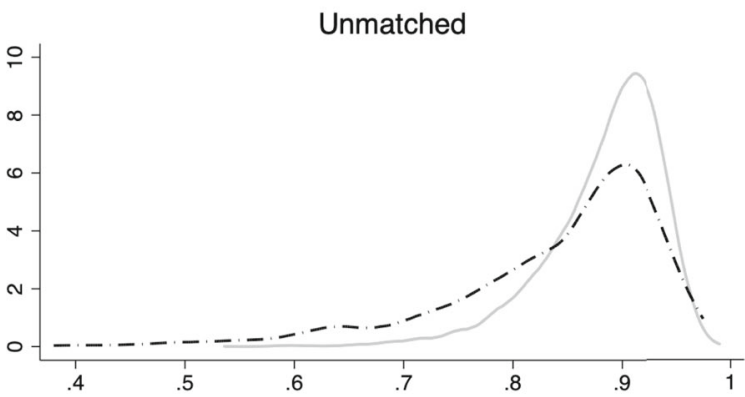

Matched

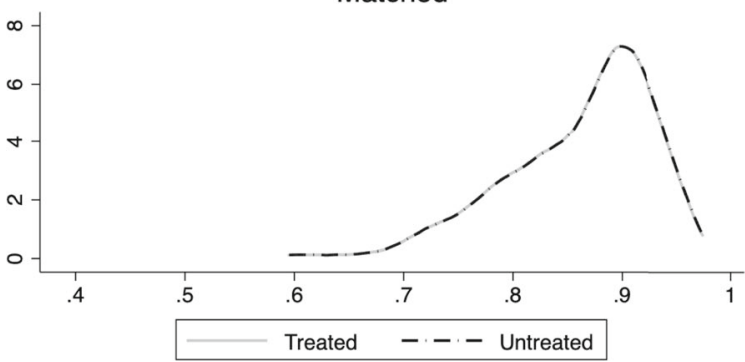

(a) Relationship Length

\section{Balancing test for PSM}

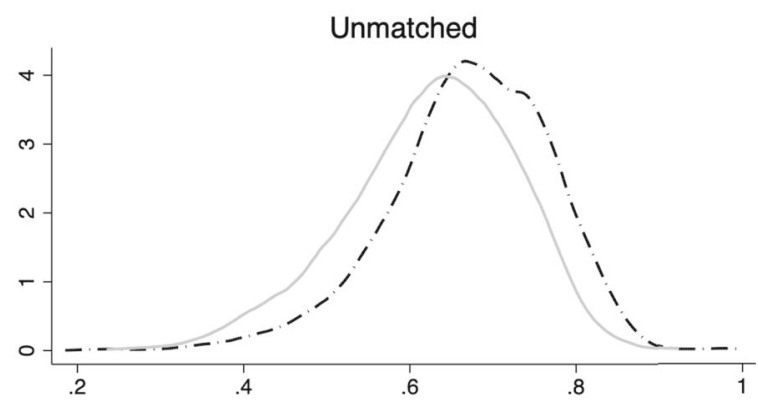

Matched

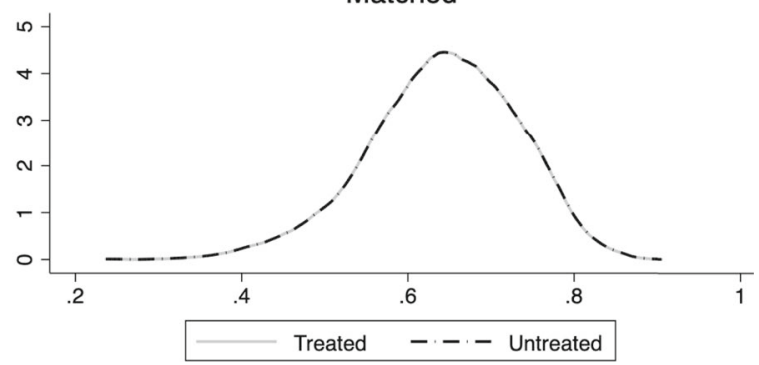

(b) Financing Share

Fig. 2 Balancing test for the propensity score matching (PSM). This figure reports the performance of the balancing test between firms with high (treated group) and low (control group) relationship lending for the sample before and after matching

Table 9 Additional test

Tobit estimations

Dependent Variables

Accounts Payable / Total Assets

(1)

(2)

Relationship Length $(\log )$

$0.002 * * *$

(0.000)

Financing Share

$0.021 * *$

(0.010)

Sales $(\log )$

$0.061 * * *$

$0.060 * * *$

(0.000)

(0.003)

Age $(\log )$

$-0.002 * * *$

0.001

(0.000)

$(0.003)$

Sales Growth

$0.080 * * *$

$0.089 * * *$

(0.002)

(0.011)

Short-term Debt Ratio

$0.208 * * *$

$0.272 * * *$

(0.003)

(0.017)

Liquidity Ratio

$0.645 * * *$

$0.734 * * *$ 
Table 9 (continued)

Tobit estimations

Dependent Variables

Accounts Payable / Total Assets

(1)

(2)

\begin{tabular}{|c|c|c|}
\hline & $(0.002)$ & $(0.216)$ \\
\hline \multirow[t]{2}{*}{ ROA } & $-0.068 * * *$ & -0.063 \\
\hline & $(0.008)$ & $(0.040)$ \\
\hline \multirow[t]{2}{*}{ Asset Tangibility } & $0.470 * * *$ & $0.567 * * *$ \\
\hline & $(0.003)$ & $(0.216)$ \\
\hline \multirow[t]{2}{*}{ Cashflow (Log) } & $-0.004 * * *$ & 0.000 \\
\hline & $(0.000)$ & $(0.003)$ \\
\hline \multirow[t]{2}{*}{ Listed } & $-0.076 * * *$ & $-0.078 * * *$ \\
\hline & $(0.001)$ & $(0.016)$ \\
\hline \multirow[t]{2}{*}{ Group } & $-0.026 * * *$ & $-0.026 * * *$ \\
\hline & $(0.001)$ & $(0.005)$ \\
\hline \multirow[t]{2}{*}{ Financial Development } & $0.025 * * *$ & 0.109 \\
\hline & $(0.002)$ & $(0.087)$ \\
\hline \multirow[t]{2}{*}{ Constant } & $-1.819 * * *$ & $-1.387 * * *$ \\
\hline & $(0.002)$ & $(0.220)$ \\
\hline Industry Dummies & Yes & Yes \\
\hline Province Dummies & Yes & Yes \\
\hline Survey Dummies & Yes & Yes \\
\hline Observations & 13,172 & 9116 \\
\hline Pseudo R-squared & 0.946 & 0.900 \\
\hline
\end{tabular}

The table reports Tobit estimates. Three, two, and, one star (*) mean, respectively, a 99, 95, and 90\% level of significance. Standard errors clustered at the firm level are in parentheses. All of the variables are defined in Table 1. Control variables are computed as average values over the 3 years of the survey 


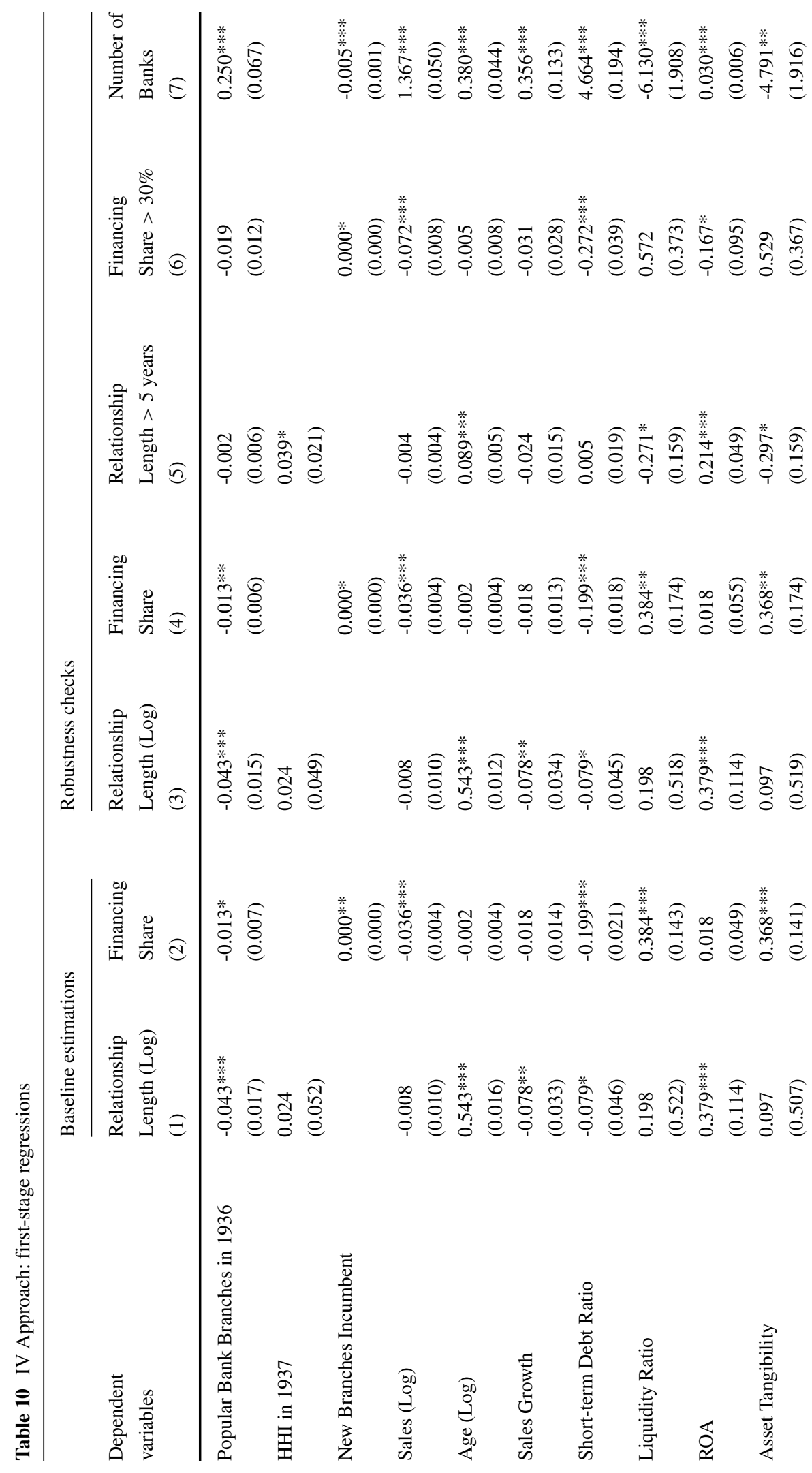




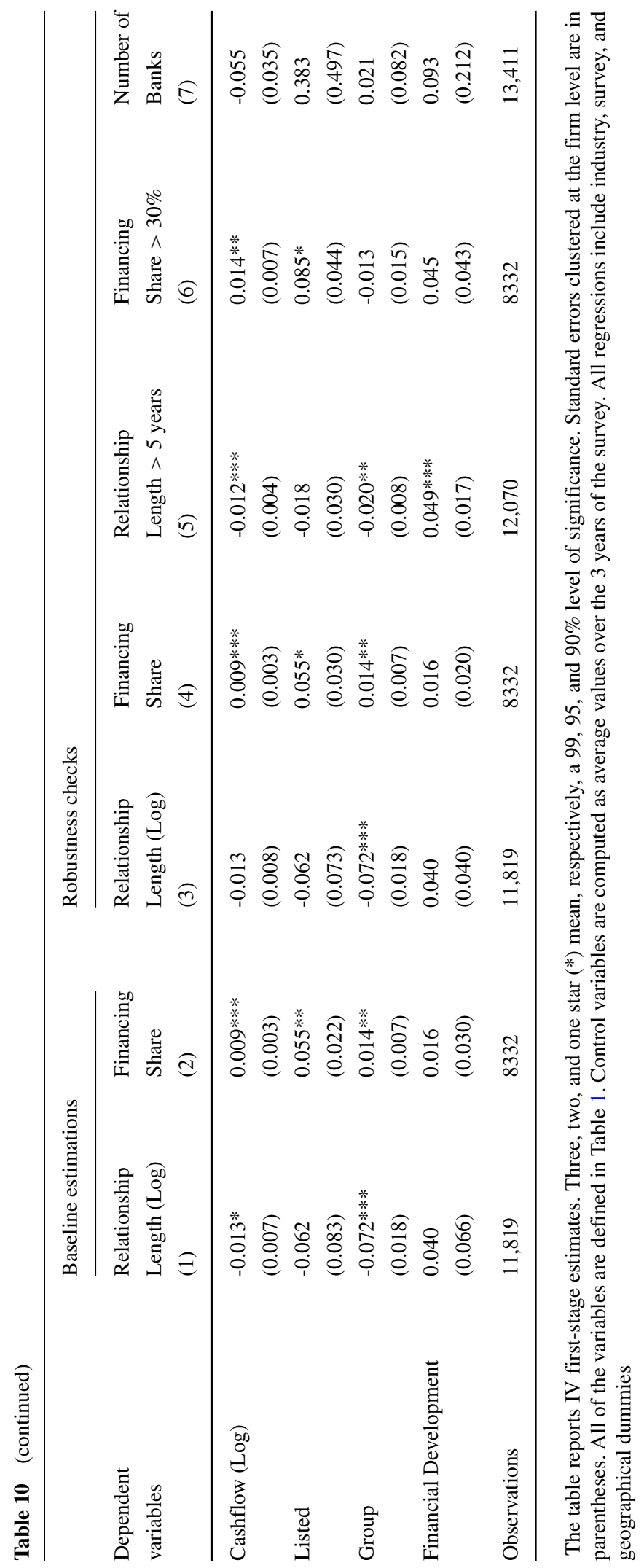


Table 11 Which of these characteristics are key in selecting your main bank?

\begin{tabular}{lllll}
\hline & Not at all (\%) & Little (\%) & Enough (\%) & Very much (\%) \\
\hline Relationship with the firm's CEO & 20.70 & 4.69 & 44.92 & 29.69 \\
Relationship with the firm's Owner & 22.27 & 7.88 & 54.75 & 15.10 \\
Frequent contacts with the Loan Officer & 20.83 & 11.07 & 52.21 & 15.89 \\
Knowledge of the firm's Industry & 20.64 & 9.90 & 53.97 & 15.49 \\
Knowledge of the firm's Local Community & 20.25 & 10.35 & 56.45 & 12.96 \\
Knowledge of the firm's Market & 22.33 & 11.85 & 56.12 & 9.70 \\
\hline
\end{tabular}

Table 12 The role of private information: additional measures

\begin{tabular}{|c|c|c|c|c|}
\hline \multirow{4}{*}{ Dependent variables } & \multicolumn{4}{|c|}{ Panel A: Alternative measure of firm size (Sales) } \\
\hline & \multicolumn{2}{|c|}{ Sales $<50$ million } & \multicolumn{2}{|c|}{ Sales $\geq 50$ million } \\
\hline & \multicolumn{2}{|c|}{ Accounts Payable / Total Assets } & \multicolumn{2}{|c|}{ Accounts Payable / Total Assets } \\
\hline & (1) & (2) & (3) & (4) \\
\hline Relationship Length (Log) & $\begin{array}{l}0.003 * \\
(0.001)\end{array}$ & & $\begin{array}{l}-0.001 \\
(0.004)\end{array}$ & \\
\hline Financing Share & & $\begin{array}{l}0.022 * * * \\
(0.008)\end{array}$ & & $\begin{array}{l}-0.007 \\
(0.014)\end{array}$ \\
\hline + Control Variables & Yes & Yes & Yes & Yes \\
\hline Observations & 9972 & 7429 & 1211 & 903 \\
\hline R-squared & 0.238 & 0.248 & 0.339 & 0.373 \\
\hline
\end{tabular}

Panel B: Alternative measure of firm size (Total Assets)

Dependent variables

Total Assets < 43 million

Accounts Payable / Total Assets

(1) (2)

$0.002 * *$

(0.001)

Financing Share

+ Control Variables

Observations

R-squared

Dependent variables
Yes

9870

0.250
Panel C: Listing status
Total Assets $\geq 43$ million

Accounts Payable / Total Assets

(3)

(4)

\subsection{0}

(0.003)

$0.021 * *$

$-0.017$

(0.008)

(0.014)

Yes

Yes

$1319 \quad 982$

0.353
7350

0.257

\section{Listed $=0$}

Accounts Payable / Total Assets

(1)

$0.002 *$

$(0.001)$

(2)
Relationship Length (log)

Financing Share

\section{Listed $=1$}

Accounts Payable / Total Assets

(3)

(4)

0.001

(0.020) 
Table 12 (continued)

\begin{tabular}{|c|c|c|c|c|}
\hline \multirow{4}{*}{ Dependent variables } & \multicolumn{4}{|c|}{ Panel D: Alternative measure of firm size (Sales) } \\
\hline & \multicolumn{2}{|c|}{ Sales $<50$ million } & \multicolumn{2}{|c|}{ Sales $\geq 50$ million } \\
\hline & \multicolumn{2}{|c|}{ Accounts Payable / Total Assets } & \multicolumn{2}{|c|}{ Accounts Payable / Total Assets } \\
\hline & (1) & $(2)$ & (3) & (4) \\
\hline & \multicolumn{2}{|r|}{$(0.008)$} & & $(0.053)$ \\
\hline + Control Variables & Yes & Yes & Yes & Yes \\
\hline Observations & 11,963 & 8240 & 142 & 92 \\
\hline R-squared & 0.199 & 0.208 & 0.765 & 0.903 \\
\hline
\end{tabular}

The table reports OLS coefficients. Three, two, and one star $(*)$ mean, respectively, a 99, 95, and 90\% level of significance. Standard errors clustered at the firm level are in parentheses. In panel A, firms are classified as having less (columns 1-2) or more (columns 3-4) than 50 million of sales, the threshold used by the European Commission to define small and medium-sized enterprises. In panel B, firms are classified as having less (columns 1-2) or more (columns 3-4) than 43 million of total assets, the threshold used by the European Commission to define small and medium-sized enterprises. In panel C, firms are classified as being (columns 1-2) or not being (columns 3-4) listed in the stock market. All of the variables are defined in Table 1. Control variables are computed as average values over the 3 years of the survey. All regressions include industry, survey, and geographical dummies

\section{Appendix B: Credit rationing}

In this section, we investigate whether the association between relationship lending and the use of trade credit is affected by firms' credit rationing. More specifically, in Table 13 we classify sample firms as being or not being rationed by banks. To create our credit rationing measure, we rely on the following questions of the Survey on Italian Manufacturing Firms: In the last year, would the firm have liked to obtain more credit at the market interest rate?; In the last year, did the firm demand more credit than

Table 13 Credit rationing

\begin{tabular}{|c|c|c|c|c|}
\hline \multirow{3}{*}{ Dependent variables } & \multicolumn{2}{|c|}{ Credit Rationing $=1$} & \multicolumn{2}{|c|}{ Credit Rationing $=0$} \\
\hline & \multicolumn{2}{|c|}{ Accounts Payable / Total Assets } & \multicolumn{2}{|c|}{ Accounts Payable / Total Assets } \\
\hline & (1) & (2) & (3) & (4) \\
\hline \multirow[t]{2}{*}{ Relationship Length (log) } & -0.019 & & $0.003 *$ & \\
\hline & $(0.012)$ & & $(0.002)$ & \\
\hline \multirow[t]{2}{*}{ Financing Share } & & -0.063 & & $0.012 *$ \\
\hline & & $(0.060)$ & & $(0.008)$ \\
\hline + Control Variables & Yes & Yes & Yes & Yes \\
\hline Industry Dummies & Yes & Yes & Yes & Yes \\
\hline Province Dummies & Yes & Yes & Yes & Yes \\
\hline Survey Dummies & Yes & Yes & Yes & Yes \\
\hline Observations & 397 & 348 & 11,541 & 7920 \\
\hline R-squared & 0.403 & 0.427 & 0.200 & 0.211 \\
\hline
\end{tabular}

The table reports OLS coefficients. Three, two, and one star $\left(^{*}\right)$ mean, respectively, a 99, 95, and 90\% level of significance. Standard errors clustered at the firm level are in parentheses. All of the variables are defined in Table 1. Control variables are computed as average values over the 3 years of the survey 
it actually obtained?. Following Angelini and Generale (2008) and Minetti and Zhu (2011), we classify as credit rationed those firms that gave a positive response to both questions. Focusing on non-rationed firms allows us to clean out the possible confounding effect of credit rationing on trade credit. By improving credit availability, relationship lending can reduce firms' need for the use of trade credit (Minetti et al., 2019). This in turn may imply a negative association between relationship lending and accounts payable for the subsample of non-credit rationed firms. Estimation results for non-rationed companies are reported in columns (3)-(4). Regression coefficients indicate that the association between relationship lending and trade credit is still positive and statistically significant. On the contrary, relationship lending is negatively and non significantly correlated with the use of trade credit for the subsample of rationed firms (columns 1-2).

Funding Open access funding provided by Luiss University within the CRUI-CARE Agreement.

Open Access This article is licensed under a Creative Commons Attribution 4.0 International License, which permits use, sharing, adaptation, distribution and reproduction in any medium or format, as long as you give appropriate credit to the original author(s) and the source, provide a link to the Creative Commons licence, and indicate if changes were made. The images or other third party material in this article are included in the article's Creative Commons licence, unless indicated otherwise in a credit line to the material. If material is not included in the article's Creative Commons licence and your intended use is not permitted by statutory regulation or exceeds the permitted use, you will need to obtain permission directly from the copyright holder. To view a copy of this licence, visit http:// creativecommons.org/licenses/by/4.0/.

\section{References}

Agarwal, S., \& Hauswald, R. (2010). Distance and private information in lending. The Review of Financial Studies, 23(7), 2757-2788. https://doi.org/10.1093/rfs/hhq001.

Agostino, M., \& Trivieri, F. (2014). Does trade credit play a signaling role? Some evidence from SMEs microdata. Small Business Economics, 42, 131-151. https://doi.org/10.1007/s11187-013-9478-8.

Amore, M. D., \& Bennedsen, M. (2013). The value of local political connections in a low-corruption environment. Journal of Financial Economics, 110(2), 387-402. https://doi.org/10.1016/j.jfineco.2013.06.002.

Andrieu, G., Stagliano, R., \& Van Der Zwan, P. (2018). Bank debt and trade credit for SMEs in Europe: firm-, industry-, and country-level determinants. Small Business Economics, 51, 245-264. https://doi.org/10.1007/s11187-017-9926-y.
Angelini, P., Di Salvo, R., \& Ferri, G. (1998). Availability and cost of credit for small businesses: customer relationships and credit cooperatives. Journal of Banking Finance, 22, 925-954. https://doi.org/10.1016/S0378-4266(98)00008-9.

Angelini, P., \& Generale, A. (2008). On the evolution of firm size distributions. American Economic Review, 98(1), 42638. https://doi.org/10.1257/aer.98.1.426.

Atanasova, C. (2012). How do firms choose between intermediary and supplier finance?. Financial Management, 41, 207228. https://doi.org/10.1111/j.1755-053X.2012.01183.x.

Atanasova, C. V., \& Wilson, N. (2004). Disequilibrium in the UK corporate loan market. Journal of Banking Finance, 28, 595-614. https://doi.org/10.1016/S0378-4266(03)00037-2.

Bartoli, F., Ferri, G., Murro, P., \& Rotondi, Z. (2013). SME Financing and the choice of lending technology in Italy: Complementarity or substitutability?. Journal of Banking Finance, 37(12), 5476-5485. https://doi.org/10.1016/j.jbankfin.2013.08.007.

Beck, T., Degryse, H., De Haas, R., \& Van Horen, N. (2018). When arm's length is too far: Relationship banking over the credit cycle. Journal of Financial Economics, 127(1), 174196. https://doi.org/10.1016/j.jfineco.2017.11.007.

Berger, AN., \& Udell, G. F. (1995). Relationship lending and lines of credit in small firm finance. Journal of Business, pp 351-381.

Berger, A. N., \& Udell, G. F. (2002). Small business credit availability and relationship lending: The importance of bank organisational structure. The Economic Journal, 112(477), F32-F53. https://doi.org/10.1111/1468-0297.00682.

Biais, B., \& Gollier, C. (1997). Trade credit and credit rationing. The Review of Financial Studies, 10, 903-937. https://doi.org/10.1093/rfs/10.4.903.

Bolton, P., Freixas, X., Gambacorta, L., \& Mistrulli, P.E. (2016). Relationship and transaction lending in a crisis. The Review of Financial Studies, 29(10), 2643-2676. https://doi.org/10.1093/rfs/hhw041.

Brennan, M. J., Maksimovics, V., \& Zechner, J. (1988). Vendor financing. The Journal of Finance, 43, 1127-1141.

Brick, I. E., \& Palia, D. (2007). Evidence of jointness in the terms of relationship lending. Journal of Financial Intermediation, 16(3), 452-476. https://doi.org/10.1016/j.jfi.2007.01.001.

Burkart, M., \& Ellingsen, T. (2004). In-kind finance: a theory of trade credit. American Economic Review, 94(3), 569-590. https://doi.org/10.1257/0002828041464579.

Carbó-Valverde, S., Rodriguez-Fernandez, F., \& Udell, G.F. (2016). Trade credit, the financial crisis, and SME access to finance. Journal of Money Credit and Banking, 48(1), 113-143. https://doi.org/10.1111/jmcb.12292.

Casey, E., \& O'Toole, C. M. (2014). Bank lending constraints, trade credit and alternative financing during the financial crisis: Evidence from European SMEs. Journal of Corporate Finance, 27, 173-193. https://doi.org/10.1016/j.jcorpfin.2014.05.001.

Cassia, L., \& Vismara, S. (2009). Firms' trade credit and the local level of development of the banking system in Europe. Investment Management and Financial Innovations, 6, 4658.

Cenni, S., Monferrá, S., Salotti, V., Sangiorgi, M., \& Torluccio, G. (2015). Credit rationing and relationship lending. Does firm size matter?. Journal of Banking Finance, 53, 249-265. https://doi.org/10.1016/j.jbankfin.2014.12.010. 
Choi, W. G., \& Kim, Y. (2005). Trade credit and the effect of macro-financial shocks: Evidence from US panel data. Journal of Financial and Quantitative Analysis, 40, 897-925.

Cook, L. D. (1999). Trade credit and bank finance: Financing small firms in Russia. Journal of Business Venturing, 14, 493-518. https://doi.org/10.1016/S0883-9026(98)00026-3.

Cosci, S., Guida, R., \& Meliciani, V. (2020). Does trade credit really help relieving financial constraints?. European Financial Management, 26, 198-215. https://doi.org/10.1111/eufm.12211.

Cousins, P. D., Handfield, R. B., Lawson, B., \& Petersen, K.J. (2006). Creating supply chain relational capital: The impact of formal and informal socialization processes. Journal of Operations Management, 24(6), 851863. https://doi.org/10.1016/j.jom.2005.08.007.

Cucculelli, M., Peruzzi, V., \& Zazzaro, A. (2019). Relational capital in lending relationships: Evidence from European family firms. Small Business Economics, 52(1), 277-301. https://doi.org/10.1007/s11187-018-0019-3.

Cunat, V. (2007). Trade credit: suppliers as debt collectors and insurance providers. The Review of Financial Studies, 20, 491-527. https://doi.org/10.1093/rfs/hhl015.

De Bonis, R., Pozzolo, A., \& Stacchini, M. (2012). The Italian banking system: Facts and interpretations. University of Molise, Dept. EGSeI.

Degryse, H., \& Ongena, S. (2005). Distance, lending relationships, and competition. The Journal of Finance, 60(1), 231266. https://doi.org/10.1111/j.1540-6261.2005.00729.x.

Deloof, M., \& La Rocca, M. (2015). Local financial development and the trade credit policy of Italian SMEs. Small Business Economics, 44, 905-924. https://doi.org/10.1007/s11187-014-9617-x.

D’Onofrio, A., Minetti, R., \& Murro, P. (2019). Banking development, socioeconomic structure and income inequality. Journal of Economic Behavior Organization, 157, 428451. https://doi.org/10.1016/j.jebo.2017.08.006.

ECB (2011). Monthly Bulletin, April.

European Commission (2015). Ex-post evaluation of late payment directive Directorate-General for Internal Market, Industry Entrepreneurship and SMEs.

Fang, V. W., Tian, X., \& Tice, S. (2014). Does stock liquidity enhance or impede firm innovation?. The Journal of Finance, 69(5), 2085-2125. https://doi.org/10.1111/jofi.12187.

Ferri, G., Minetti, R., \& Murro, P. (2019a). Credit Relationships in the great trade collapse. Micro evidence from Europe. Journal of Financial Intermediation, 40, 100809. https://doi.org/10.1016/j.jfi.2019.01.001.

Ferri, G., Murro, P., Peruzzi, V., \& Rotondi, Z. (2019b). Bank lending technologies and credit availability in Europe: What can we learn from the crisis?. Journal of International Money and Finance, 95, 128-148. https://doi.org/10.1016/j.jimonfin.2019.04.003.

Ferris, J. S. (1981). A transactions theory of trade credit use. The Quarterly Journal of Economics, 96, 243-270. https://doi.org/10.2307/1882390.

Frank, M. Z., \& Maksimovic, v. (2005). Trade Credit. Collateral and Adverse Selection. University of Maryland Working Paper.
Gambini, A., \& Zazzaro, A. (2013). Long-lasting bank relationships and growth of firms. Small Business Economics, 40 , 977-1007. https://doi.org/10.1007/s11187-011-9406-8.

Garcia-Appendini, E. (2011). Supplier certification and trade credit. Available at SSRN 1795107.

Garcia-Appendini, E., \& Montoriol-Garriga, J. (2013). Firms as liquidity providers: Evidence from the 2007-2008 financial crisis. Journal of Financial Economics, 109, 272-291. https://doi.org/10.1016/j.jfineco.2013.02.010.

Giannetti, M., Burkart, M., \& Ellingsen, T. (2011). What you sell is what you lend? Explaining trade credit contracts. The Review of Financial Studies, 24, 1261-1298. https://doi.org/10.1093/rfs/hhn096.

Guiso, L., Sapienza, P., \& Zingales, L. (2003). The Cost of Banking Regulation. Unpublished working paper. Chicago Graduate School of Business.

Guiso, L., Sapienza, P., \& Zingales, L. (2004). Does local financial development matter?. The Quarterly Journal of Economics, 119(3), 929-969. https://doi.org/10.1162/0033553041502162.

Herrera, A. M., \& Minetti, R. (2007). Informed finance and technological change: Evidence from credit relationships. Journal of Financial Economics, 83(1), 223-269. https://doi.org/10.1016/j.jfineco.2005.12.001.

Hormiga, E., Batista-Canino, R. M., \& Sánchez-Medina, A. (2011). The impact of relational capital on the success of new business start-ups. Journal of Small Business Management, 49(4), 617-638. https://doi.org/10.1111/j.1540-627X.2011.00339.x.

Klapper, L., Laeven, L., \& Rajan, R. (2012). Trade credit contracts. The Review of Financial Studies, 25, 838-867. https://doi.org/10.1093/rfs/hhr122.

Kong, D., Pan, Y., Tian, G. G., \& Zhang, P. (2020). CEOS' hometown connections and access to trade credit: Evidence from China. Journal of Corporate Finance, 62, 101574. https://doi.org/10.1016/j.jcorpfin.2020.101574.

Kranton, R. E., \& Minehart, D. F. (2001). A theory of buyerseller networks. American Economic Review, 91(3), 485508. https://doi.org/0.1257/aer.91.3.485.

Mateut, S., Bougheas, S., \& Mizen, P. (2006). Trade credit, bank lending and monetary policy transmission. European Economic Review, 50, 603-629. https://doi.org/10.1016/j.euroecorev.2005.01.002.

McGuinness, G., Hogan, T., \& Powell, R. (2018). European trade credit use and SME survival. Journal of Corporate Finance, 49, 81-103. https://doi.org/10.1016/j.jcorpfin.2017.12.005.

McMillan, J., \& Woodruff, C. (1999). Interfirm relationships and informal credit in Vietnam. The Quarterly Journal of Economics, 114, 1285-1320. https://doi.org/10.1162/003355399556278.

Mian, S. L., \& Smith Jr, C. W. (1992). Accounts receivable management policy: Theory and evidence. The Journal of Finance, 47(1), 169-200. https://doi.org/10.1111/j.1540-6261.1992.tb03982.x.

Minetti, R., Mulabdic, A., Ruta, M., \& Zhu, S.C. (2021a). Financial structures, banking regulations, and export dynamics. Journal of Banking Finance, 124, 106056. https://doi.org/10.1016/j.jbankfin.2021.106056. 
Minetti, R., Murro, P., \& Paiella, M. (2015). Ownership structure, governance, and innovation. European Economic Review, 80, 165-193. https://doi.org/10.1016/j.euroecorev.2015.09.007.

Minetti, R., Murro, P., \& Peruzzi, V. (2021b). Not all banks are equal: Cooperative banking and income inequality. Economic Inquiry, 59(1), 420-440. https://doi.org/10.1111/ecin.12932.

Minetti, R., Murro, P., Rotondi, Z., \& Zhu, S.C. (2019). Financial constraints, firms' supply chains, and internationalization. Journal of the European Economic Association, 17(2), 327-375. https://doi.org/10.1093/jeea/jvx056.

Minetti, R., \& Zhu, S. C. (2011). Credit constraints and firm export: Microeconomic evidence from Italy. Journal of International Economics, 83(2), 109-125. https://doi.org/10.1016/j.jinteco.2010.12.004

Murro, P., Oliviero, T., \& Zazzaro, A. (2020). The role of relationship lending on employment decisions in firms' bad times (no. 533) centre for studies in economics and finance (CSEF), University of Naples, Italy.

Murro, P., \& Peruzzi, V. (2019). Family firms and access to credit. is family ownership beneficial?. Journal of Banking Finance, 101, 173-187. https://doi.org/10.1016/j.jbankfin.2019.02.006.

Ng, C. K., Smith, J. K., \& Smith, R.L. (1999). Evidence on the determinants of credit terms used in interfirm trade. The Journal of Finance, 54(3), 1109-1129. https://doi.org/10.1111/0022-1082.00138.

Nilsen, J. H. (2002). Trade credit and the bank lending channel. Journal of Money Credit and Banking, pp 226253.

Nunn, N. (2007). Relationship-specificity, incomplete contracts, and the pattern of trade. The Quarterly Journal of Economics, 122(2), 569-600. https://doi.org/10.1162/qjec.122.2.569.

Palacń-Sánchez, M. J., Canto-Cuevas, F. J., \& diPietro, F. (2019). Trade credit versus bank credit: a simultaneous analysis in European SMEs. Small Business Economics, 53(4), 1079-1096. https://doi.org/10.1007/s11187-018-0101-x.

Peruzzi, V. (2017). Does family ownership structure affect investment-cash flow sensitivity? Evidence from Italian SMEs. Applied Economics, 49(43), 4378-4393. https://doi.org/10.1080/00036846.2017.1282147.
Petersen, M. A., \& Rajan, R. G. (1994). The benefits of lending relationships: Evidence from small business data. The Journal of Finance, 49, 3-37. https://doi.org/10.1111/j.1540-6261.1994.tb04418.x.

Petersen, M. A., \& Rajan, R. G. (1997). Trade credit: theories and evidence. The Review of Financial Studies, 10, 661691. https://doi.org/10.1093/rfs/10.3.661.

Psillaki, M., \& Eleftheriou, K. (2015). Trade Credit, Bank Credit, and Flight to Quality: Evidence from French SME s. Journal of Small Business Management, 53(4), 1219-1240. https://doi.org/10.1111/jsbm.12106.

Russo, P. F., \& Leva, L. (2004). Il debito commerciale in Italia: quanto contano le motivazioni finanziarie? (No 496). Bank of Italy, Economic Research and International Relations Area.

Salvato, C., \& Melin, L. (2008). Creating value across generations in family-controlled businesses: The role of family social capital. Family business review, 21(3), 259-276. https://doi.org/10.1177/08944865080210030107.

Santikian, L. (2014). The ties that bind: Bank relationships and small business lending. Journal of Financial Intermediation, 23(2), 177-213. https://doi.org/10.1016/j.jfi.2013.11.004.

Sette, E., \& Gobbi, G. (2015). Relationship lending during a financial crisis. Journal of the European Economic Association, 13(3), 453-481. https://doi.org/10.1111/jeea.12111.

Smith, J. K. (1987). Trade credit and informational asymmetry. The Journal of Finance, 42, 863-872. https://doi.org/10.1111/j.1540-6261.1987.tb03916.x.

Uchida, H., Udell, G. F., \& Watanabe, W. (2013). Are trade creditors relationship lenders?. Japan and the World Economy, 25, 24-38. https://doi.org/10.1016/j.japwor.2013.01.002.

Wilner, B. S. (2000). The exploitation of relationships in financial distress: The case of trade credit. The Journal of Finance, 55, 153-178. https://doi.org/10.1111/0022-1082.00203.

World Bank. (2002). World development indicators. Washington, D.C: World Bank.

Publisher's note Springer Nature remains neutral with regard to jurisdictional claims in published maps and institutional affiliations. 